\title{
The relationship between physical function and experience of fatigue in patients with chronic obstructive pulmonary disease
}

\author{
Kristina Tödt \\ Department of Social and Welfare Studies \\ Division Health, Activity, Care \\ Linköping University, Sweden
}

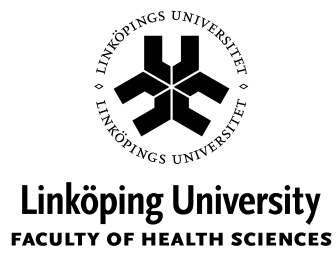

Linköping 2014 
CKristina Tödt, 2014

Cover picture/illustration: Kristina Tödt

Published article has been reprinted with the permission of the copyright holder.

Printed in Sweden by LiU-Tryck, Linköping, Sweden, 2014

ISBN 978-91-7519-425-7

ISSN 1100-6013 
To the praise of His glorious grace!

....and to my husband Tim! 



\section{CONTENTS}

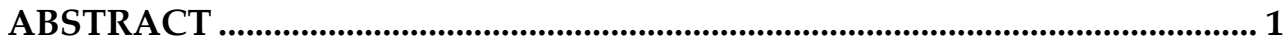

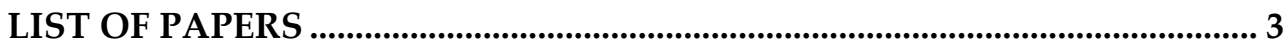

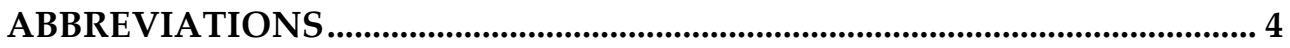

BACKGROUND.................................................................................................. 5

Chronic Obstructive Pulmonary Disease ................................................... 5

Physical function...................................................................................... 7

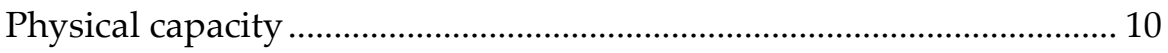

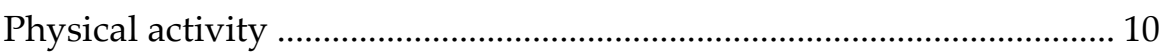

Symptoms and symptom burden........................................................... 12

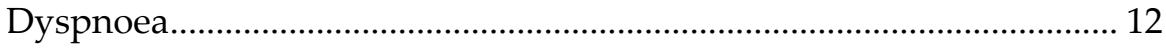

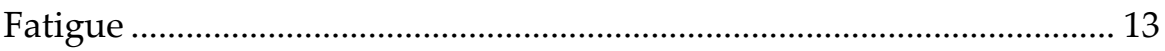

Depression and anxiety .................................................................... 16

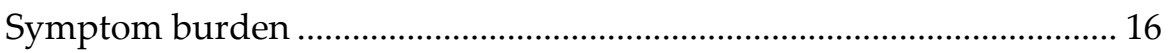

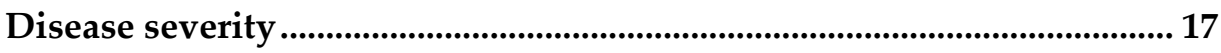

Body composition ........................................................................................... 18

Rationale of this thesis.......................................................................... 19

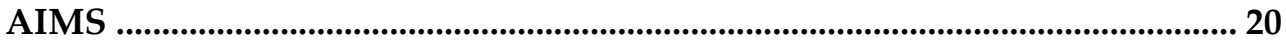

PATIENTS AND METHODS..................................................................... 21

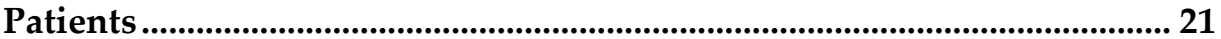

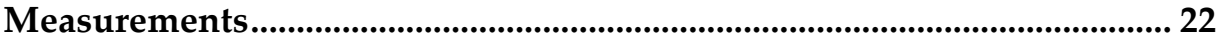

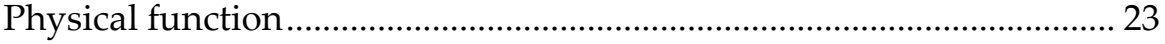

Symptoms and symptom burden ....................................................... 27

Body Measurements .......................................................................... 29

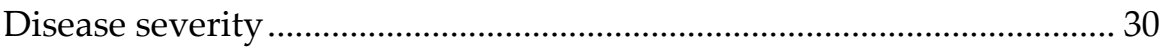

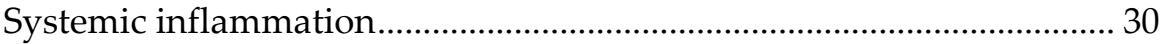




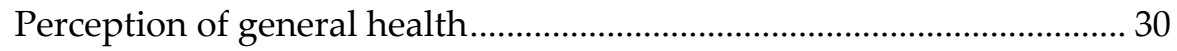

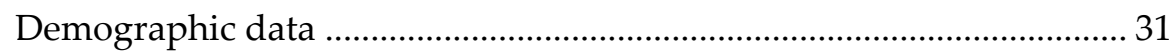

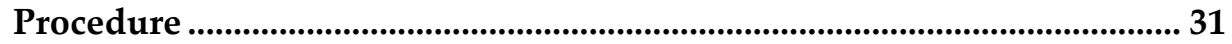

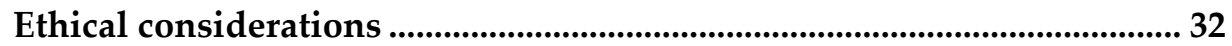

Statistical Analysis.................................................................................................. 32

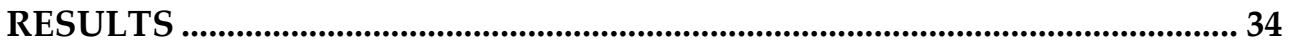

Level of physical activity .................................................................................. 35

Experience of fatigue ........................................................................................... 36

Factors associated with low physical activity (paper I) .................................. 37

The relationship between experience of fatigue and factors of physical capacity and disease severity in men and women (paper II) ...................... 39

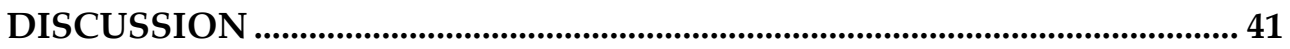

Factors associated with low physical activity.................................................. 41

The relationship between experience of fatigue and physical capacity and disease severity in men and women........................................................... 43

Methodological issues and limitations.......................................................... 46

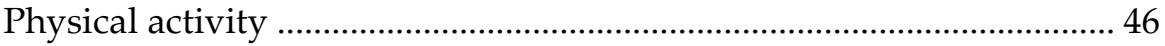

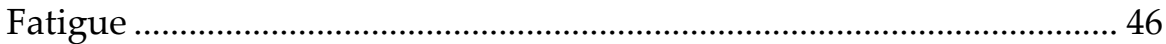

Clinical implications and future research ......................................................... 47

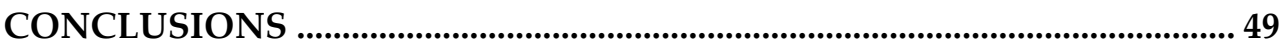

POPULÄRVETENSKAPLIG SAMMANFATTNING (SUMMARY IN

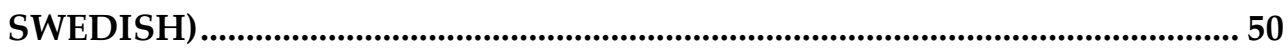

ACKNOWLEDGEMENTS ................................................................................... 52

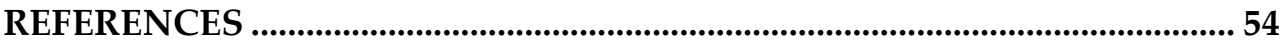




\title{
ABSTRACT
}

\section{Background}

Chronic Obstructive Pulmonary Disease (COPD) is increasing throughout the world and most rapidly among women. COPD is characterized by a progressive loss of physical functions. The reason for this is multi-factorial and include not only lung related deficiencies but also several systemic consequences and symptoms of which several are potential restrictors of physical function. The relationship between physical function and symptoms are not clear, especially not among women with COPD.

\begin{abstract}
Aim
The overall aim of this thesis was to illuminate the relationship between two dimensions of physical function (physical activity and physical capacity) and experience of fatigue. The specific aims were to explore factors associated with low physical activity and to examine experience of fatigue and its relationship to physical capacity and disease severity in men and women with COPD.
\end{abstract}

\section{Methods}

A cross-sectional study was conducted including 121 patients (67 women) with stable COPD and mean age of $67(+/-7)$ years. Physical activity was measured with the International Physical Activity Questionnaire short form. Physical capacity included assessment of lung function (dynamic spirometry), exercise capacity (the 6-minute walk distance [perceived dyspnoea and leg fatigue in connection to the test]) and muscle strength (the Timed Stands Test and grip strength). Fatigue was assessed with structured questions covering the frequency, duration and severity of fatigue the previous month and patients were categorized as those with no fatigue, moderate fatigue or severe fatigue. Data about other symptoms (dyspnoea, anxiety and depression), symptom burden (Memorial Symptom Assessment Scale), fat and fat free mass (bio-impedance analysis) and smoking history was collected. 


\section{Results}

Forty-two percent of the patients reported a low physical activity level. A majority of the patients reported experience of fatigue the previous month, $52 \%$ moderate fatigue and $25 \%$ severe fatigue. Low physical activity was associated with severe fatigue, worse exercise capacity and a higher amount of smoking. There were no differences in experience of fatigue between men and women. Men with fatigue had worse physical capacity and disease severity compared to men without fatigue. Women with fatigue had comparable physical capacity and disease severity to women without fatigue except for a higher perceived leg fatigue after the exercise capacity test. Multiple logistic regression analysis showed that exercise capacity and disease severity were associated with fatigue in both men and women but in women, leg fatigue was also strongly associated with the presence of fatigue.

\section{Conclusions}

Severe fatigue, worse exercise capacity and a higher amount of smoking were independently associated with low PA. This result suggests that patients with severe fatigue might need specific strategies to become more physically active. Presence of fatigue was associated with exercise capacity and disease severity in both men and women. In addition, in women leg fatigue was strongly associated with fatigue. Muscle endurance training might be extra important in the rehabilitation of women with COPD experiencing fatigue. However the association between fatigue and exercised induced leg fatigue among the women warrant further investigation. 


\section{LIST OF PAPERS}

This thesis is based on the following papers, which will be referred in the text by Roman numerals.

I. Tödt K, Skargren E, Jakobsson P, Theander K, Unosson M. Factors associated with low physical activity in patients with Chronic Obstructive Pulmonary Disease. A cross-sectional study. Manuscript submitted for publication.

II. Tödt K, Skargren E, Kentson M, Theander K, Jakobsson P, Unosson M. Experience of fatigue, and its relationship to physical capacity and disease severity in men and women with COPD. International Journal of COPD 2014;9:17-25 


\section{ABBREVIATIONS}

6MWD

BMI

BODE index

CI

COPD

CRP

FEV 1

FMI

FFMI

FVC

GOLD

HADS

HRQL

Il-6

IPAQ-S

MET

MRC

MSAS

OR

PA

SD

TST
Six minute walk distance

Body Mass Index

A composite score of Body mass index, airway Obstruction, Dyspnoea, and Exercise capacity

Confidence Interval

Chronic Obstructive Pulmonary Disease

C-Reactive Protein

Forced Expiratory Volume in one second

Fat Mass Index

Fat-Free Mass Index

Forced Vital Capacity

Global Initiative for Chronic Obstructive Lung Disease Hospital Anxiety and Depression Scale

Health Related Quality of Life

Interleukin 6

International Physical Activity Questionnaire - short

Metabolic Equivalent of Task

Medical Research Council

Memorial Symptom Assessment Scale

Odds Ratio

Physical Activity

Standard Deviation

Timed Stands Test 


\section{BACKGROUND}

\section{Chronic Obstructive Pulmonary Disease}

Chronic Obstructive Pulmonary disease (COPD) is a leading cause of mortality, particularly in Western countries, and it is estimated that it will be the third leading cause of death worldwide by 2020 1. The worldwide prevalence of COPD ranges between $7.8-19.7 \%{ }^{2}$. In the Obstructive Lung Disease in Northern Sweden study ${ }^{3-4}$ a prevalence of $14.3 \%$ was found in the population $>45$ years and an increased prevalence was found with age, and among elderly smokers the prevalence was $50 \%{ }^{3}$. The prevalence of COPD is increasing throughout the world and a more rapid increase is occurring among women ${ }^{5}$. In the year 2000, there were more deaths among women from COPD than among men in the United States and in Canada ${ }^{1}$. A similar trend is seen in Sweden, with an increasing incidence among women and a stabilizing incidence among men ${ }^{6}$. According to statistics from Statistics Sweden (SCB) since 2010 the mortality in COPD has been higher among women than men.

COPD is defined as "a common, preventable and treatable disease, characterized by persistent airflow limitation that is usually progressive and associated with an enhanced chronic inflammatory response in the airways and the lungs to noxious particles or gases. Exacerbations and co-morbidities contribute to the overall severity in individual patients" 7. The clinical diagnosis is based on the presence of the characteristic symptoms of dyspnoea, cough, and sputum production, a history of exposure to risk factors, and a family history of COPD ${ }^{8}$. Tobacco smoke is the major risk factor for developing the disease ${ }^{7-8}$. Inhaled tobacco smoke and other noxious particles cause a chronic inflammation within the lungs which may cause a remodelling of the small airways which is often combined with destruction of the lung- 
parenchyma and the development of emphysema ${ }^{8-9}$. Women are suggested to be more susceptible to the effects of tobacco smoke and therefore are at higher risk of developing COPD ${ }^{10}$. Some studies have found structural differences within the lungs, with men having more emphysema than women ${ }^{11-13}$ while others have found that in women the walls of the small airways are thicker ${ }^{13}$. One study showed that severe airway obstruction was related to a more rapid decline in lung function in women than in men ${ }^{14}$.

Spirometry is required to confirm the diagnosis. According to the strategy document for the diagnosis, management and prevention of COPD from the Global Initiative of Chronic Obstructive Lung Disease (GOLD) a postbronchodilator ratio of forced expiratory volume in one second $\left(\mathrm{FEV}_{1}\right)$ over forced vital capacity $($ FVC $)<0.7$ is diagnostic ${ }^{7}$. To reduce overdiagnosis a lower ratio of 0.65 for persons above 65 has been adopted in Sweden ${ }^{15}$ but the ratio 0.7 is used internationally and was therefore used to define COPD spirometrically in this thesis. Prerequisite a ratio of FEV 1 over FVC below $<0.7$ the degree of airflow limitation can be divided into the four GOLD grades based on the percentage of predicted $\mathrm{FEV}_{1} 7$; GOLD 1, mild $=\geq 80 \%$ of predicted; GOLD 2, moderate $=50-79 \%$ of predicted; GOLD 3, severe $=30-$ $49 \%$ of predicted and GOLD 4 , very severe $=<30 \%$ of predicted.

COPD is primarily a lung disease but there is a large and growing quantity of knowledge of its multiple systemic consequences. COPD is viewed as a disease that is not only preventable but also treatable, in part by preventing and reducing the systemic consequences ${ }^{216}$. Systemic consequences, including co-morbidities, are skeletal muscle wasting and cachexia with a loss of muscle mass, ischemic heart disease, heart failure, osteoporosis, normocytic anaemia, diabetes, metabolic syndrome and depression ${ }^{16}$. The aetiology of these conditions is not fully understood 16 but the increase in markers of systemic inflammation seen in patients with COPD is pointed out to be a key factor that might be a link between the disease and the systemic manifestations ${ }^{17}$.

The management of COPD includes both pharmacologic and nonpharmacologic treatment. Smoking cessation is essential and is the only 
"treatment" that can reverse the progression of the disease ${ }^{8}$. The goal of both the pharmacological and non-pharmacological treatment is to prevent and reduce symptoms, increase functional status, reduce the risk and severity of exacerbations and improve health status ${ }^{7-8}$. Pharmacological therapy in patients with stable COPD is based on the airflow limitation but also on the individual patient's symptoms. Inhaled bronchodilators and glucocorticoids in different combinations and in some cases the addition of phosphodiesterase-4 inhibitors comprise the most important pharmacological treatment ${ }^{8}$. In cases with severe disease and respiratory failure, respiratory support such as longterm oxygen therapy has been shown to increase survival but this also includes the use of mechanical ventilation ${ }^{8}$. The non-pharmacologic treatment includes regular physical activity, pulmonary rehabilitation, and vaccination ${ }^{7-}$ 8. Exercise training is considered the cornerstone of pulmonary rehabilitation as several of the systemic consequences are amenable to physical exercise training ${ }^{18}$. Exercise training as part of pulmonary rehabilitation programs has been shown to be effective in all patients despite the degree of air-flow limitation ${ }^{18-19}$. The exercise includes endurance training aiming to increase exercise capacity, and muscle strength training both for the upper and lower limbs and the respiratory muscles ${ }^{18}$. Exercise training is just one part of pulmonary rehabilitation, and to promote long-term adherence of healthenhancing behaviours education and behaviour change are also important ${ }^{18}$.

\section{Physical function}

COPD is characterized by a slow progressive loss of physical functions, primarily a loss of lung function but also a loss of exercise capacity, muscle strength and a reduction in physical activity 16 20-22. In this thesis, physical function is, as part of functional status, defined in accordance with Leidy ${ }^{23}$. Leidy ${ }^{23}$ defines functional status as the ability to provide for the necessities of life i.e. normal life activities to meet basic needs, and fulfill one's usual roles to maintain health and wellbeing, and is individually determined ${ }^{23}$. Functional status includes all human functions (physical, psychological, social, cognitive, and spiritual). A function is conceptualized by Leidy ${ }^{23}$ as having four dimensions; 1) functional capacity, 2) functional performance, 3) functional 
reserve and 4) functional capacity utilization. In this thesis, two dimensions of physical function are in focus: physical capacity and physical performance.

Functional capacity is the maximal performance in a specific task in any of the functional domains: physical, cognitive, psychological, social, and spiritual also including socio-demographic. Physical capacity includes among others, lung function, exercise capacity as well as muscle strength and endurance ${ }^{23}$. According to Leidy, activity-induced symptoms are elements of capacity ${ }^{24}$. Physical capacity in this thesis includes measures of lung function, exercise capacity, muscle strength of both the upper and lower limbs, and the assessment of dyspnoea and leg fatigue in connection with exercise capacity testing. Functional performance refers to any activity (physical, cognitive, social etc.) that a person performs in their day-to-day life ${ }^{23}$. In this thesis, physical activity (PA) is used interchangeably with physical performance.

Functional reserve is the difference between the functional capacity and functional performance. Functional capacity utilization refers to the extent to "which functional potential is called upon in the selected level performance" and can be both underutilized and utilized to a greater extent with manifestations of symptoms such as fatigue or dyspnoea ${ }^{23}$.

The relationship between the dimensions of functional status is overviewed and applied to physical function in Figure 1. 


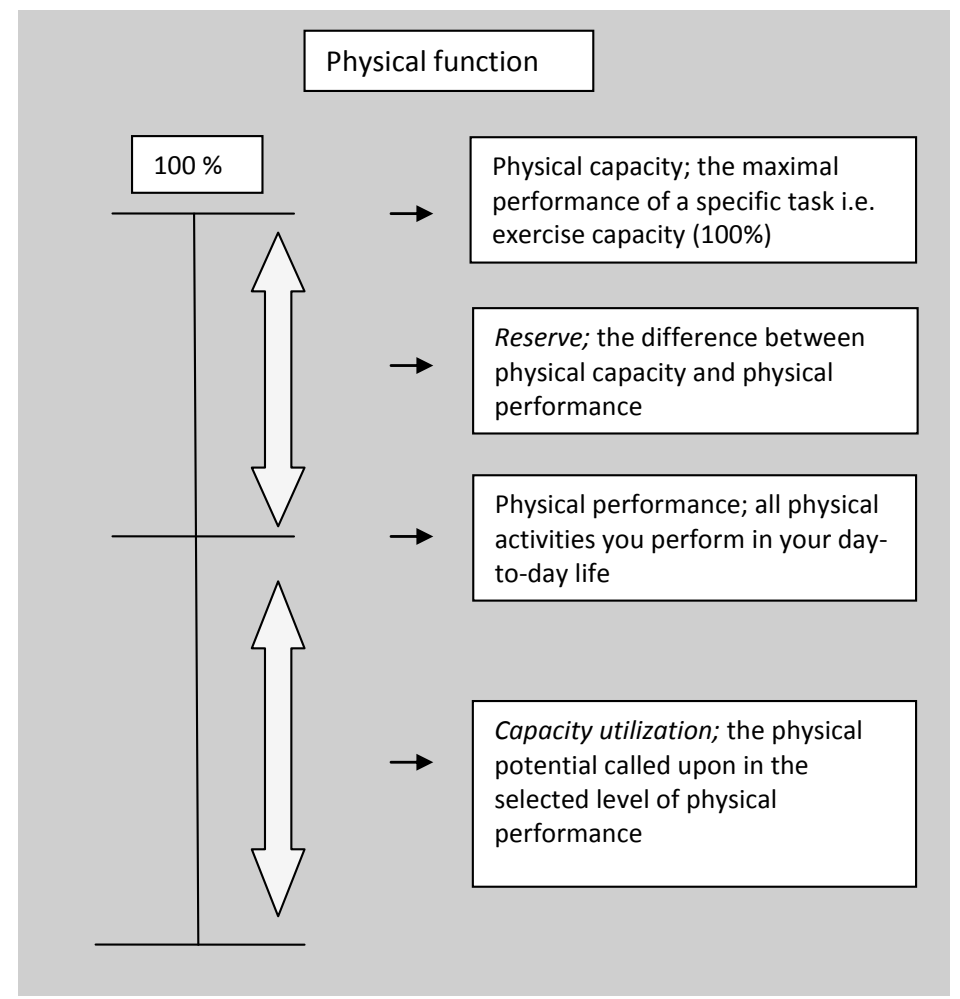

Figure 1. The relationship between the four dimensions conceptualizing functional status applied to physical function

Jeng et al. ${ }^{25}$ showed that while the absolute oxygen consumption in different tasks of daily life was similar in patients with COPD compared to healthy subjects, the patients with COPD had lower maximal oxygen consumption, i.e. aerobic capacity, and therefore used a higher proportion of their aerobic capacity, i.e. they had higher aerobic capacity utilitzation, resulting in a lower aerobic reserve. According to Leidy ${ }^{23}$ this situation may cause higher levels of dyspnoea and fatigue. 


\section{Physical capacity}

Patients with COPD are subject to a progressive reduction of physical capacity. Lung function is the most important indicator of the physical impairment in COPD ${ }^{8}$ but the progressive reduction of physical capacity is often referred to as the loss of exercise capacity 16 20-22. The impaired exercise capacity is also one of the most troublesome effects for the patients ${ }^{16}$. The mechanisms/causes behind the loss of exercise capacity are in part ascribed to respiratory limitations but are multi-factorial and are also explained by cardiovascular and skeletal muscle factors, nutritional impairment, psychological factors and physical inactivity 16 21 26-27. There has been a discussion on which factors are the most prominent restrictors of exercise capacity and three major restrictors are highlighted 1) inadequate energy supply to the respiratory and locomotor muscles, 2) lower limb muscle dysfunction, and 3) dynamic hyperinflation ${ }^{28}$. Lower limb muscle dysfunction in COPD includes loss of muscle endurance ${ }^{29-30}$, early onset of muscle fatigue ${ }^{31}$ and loss of muscle strength ${ }^{30}$.

Some studies indicate that there might be differences between men and women regarding the impact of COPD on factors of physical capacity in that women with COPD seem to be more prone to impaired thigh muscle function 32 as well as impaired exercise capacity ${ }^{33-34}$ despite similar lung function compared to men.

\section{Physical activity}

Physical activity (PA) is defined as any bodily movement produced by skeletal muscles that increase energy expenditure ${ }^{35}$. PA in daily life can be categorised into occupational, sports, household or other activities. Exercise training is a subset of PA that is planned, structured and repetitive with the purpose of improving or maintaining one or more components of physical fitness (i.e. physical capacity) ${ }^{35}$. The concept of physical activity therefore incorporates both physical fitness training and all other daily physical activities. The 
importance of physical activity for promoting and maintaining optimal health has been established not only for healthy individuals but also for individuals with chronic illnesses such as COPD ${ }^{36}$. The recommended amount of aerobic activity to maintain health is 30 minutes (can be divided into bouts of 10 minutes) five days/week of moderate intensity or 20 minutes three days/week of vigorous intensity ${ }^{36}$. This recommended amount of aerobic activity is in addition to activities of daily living such as self-care, cooking or shopping or moderate activities with a duration of less than 10 minutes ${ }^{36}$. Muscle strengthening and balance training are also included in the recommendation for elderly adults and adults with chronic diseases ${ }^{36}$. The energy needed in different activities can be described by the number of metabolic equivalents (METs). A MET is the amount of oxygen consumption at rest, approximately $3.5 \mathrm{ml} \mathrm{O} / \mathrm{kg} / \mathrm{min}$. An activity requiring two METs requires twice the resting metabolism ${ }^{37}$. Activities requiring 3-5.9 METs are defined as activities of moderate intensity ${ }^{3638}$.

Patients with COPD have lower a PA-level compared to healthy controls 39 and report significantly lower PA than individuals with other chronic illnesses ${ }^{40}$. Pitta et al. ${ }^{41}$ showed that patients with COPD spent half as much time walking compared with persons not having COPD, 44 +/- 26 vs. $81+/-26$ minutes per day, and walked with a lower intensity and spent longer sitting each day ${ }^{41}$. Patients with COPD spent less than half the time in activity of moderate intensity compared to the controls ${ }^{42}$. A matter of concern is that the reduction in daily PA starts early in the disease ${ }^{42-43}$ and most pronounced is the reduction in activities of moderate intensity ${ }^{42}$. In the study by Troosters et al. ${ }^{42}$ patients already in GOLD I spent nearly half the time doing moderate activities compared to the control subjects (> 3.5 and 4.5 METs). Physical inactivity is highlighted as an important contributor to the development of peripheral muscle dysfunction and the loss of exercise capacity seen in patients with COPD ${ }^{1628}$.

In patients with COPD, the level of physical activity is found to be a predictor of hospital admission and mortality ${ }^{44-47}$. Maintaining low PA or a decrease in PA in a five year follow-up study was associated with a significant decline in 
health-related quality of life (HRQL) while an increase in HRQL was found in those who maintained a high level of PA ${ }^{48}$.

Several factors of physical capacity such as exercise capacity $414349-51$, lung function 424652 and peripheral muscle strength ${ }^{41}$ 52-53 are associated with PA in patients with COPD. Lung function, exercise capacity and muscle strength have also been found to be important predictors of self-reported functional performance in a three year follow up study ${ }^{20}$. Disease severity ${ }^{53-55}$ and systemic inflammation 50535 have also been found to be related to PA. Except for the sound relationship between physical capacity and PA, symptoms play a central role in the vicious cycle of declining physical function in patients with COPD ${ }^{56}$.

\section{Symptoms and symptom burden}

A symptom is defined as "a subjective experience reflecting the bio-psychosocial functioning, sensations or cognition of an individual" 57 . According to the middle-range theory of unpleasant symptoms the experience of a symptom is multidimensional and can be conceptualized in terms of intensity/severity, frequency and duration, and the level of distress ${ }^{58}$. These dimensions can be measured separately or in combination. Although symptoms can occur alone, they are usually experienced simultaneously. The experience of multiple symptoms simultaneously is suggested to result in a multiplicative rather than additive experience ${ }^{58}$.

The experience of the multi-dimensional characteristics (frequency, severity and distress) of concurrent symptoms can be defined as the symptom burden 59 .

\section{Dyspnoea}

Dyspnoea is the most common and characteristic symptom in patients with COPD 760 and is seen as the central symptom limiting physical function 
(exercise capacity and physical activity) ${ }^{56} 61$. The American Thoracic Society defines dyspnoea "as a subjective experience of breathing discomfort that is comprised of qualitatively distinct sensations that vary in intensity, and derives from interactions among multiple physiological, psychological, social, and environmental factors, and may induce secondary physiological and behavioural responses"62-63. It is emphasized that dyspnoea "can only be perceived by the person experiencing it" ${ }^{\prime \prime}$.

Although dyspnoea is described as the central cause of the vicious decline in function among patients with COPD ${ }^{61}$ the relation between PA and dyspnoea is inconsistent, with no relation being found in some studies ${ }^{49-50} 64$ and a negative relation found by others 435365 .

Furthermore, there seem to be differences between the sexes regarding respiratory symptoms including dyspnoea. Despite men and women having a similar prevalence of respiratory symptoms, dyspnoea, cough, wheeze and phlegm are associated with lung function in men only ${ }^{14}$. In one study dyspnoea, exercise capacity, co-morbidity and the ratio of inspiratory capacity to total lung function explained $87 \%$ of the variation in HRQL in men but in women dyspnoea did not emerge as an explanatory variable. In women, exercise capacity and oxygen saturation explained $48 \%$ of the variation in HRQL ${ }^{33}$. The same researchers found in another study that $81 \%$ of the variation in dyspnoea was explained by oxygen saturation, diffusion capacity, the respiratory drive (the ratio of mouth occlusion pressure to maximal inspiratory pressure) and BMI in men, and in women $30 \%$ of the variation in dyspnoea was explained only by the respiratory drive ${ }^{66}$.

\section{Fatigue}

The experience of fatigue is common in people in general but is more common in individuals with chronic illnesses ${ }^{67}$. Fatigue is the second most prevalent symptom in patients with COPD 60 68-71. In line with dyspnoea fatigue is a subjective perception or sensation and can actually be defined by whatever a person says it is ${ }^{72}$. It is generally considered that fatigue is multidimensional 
both regarding the symptom itself, i.e. the frequency, timing, duration, severity and distress of fatigue, and with regard to the subjective manifestations of fatigue on mental, cognitive, physical, and emotional functions 58 72. It can be concluded that fatigue is a complex phenomenon which is best seen as a subjective sensation that can impact various functions of daily life. This thesis is based on the definition outlined in a concept analysis of fatigue by Ream and Richardson ${ }^{73}$ in which fatigue is defined as "a subjective, unpleasant symptom which incorporates total body feelings ranging from tiredness to exhaustion, creating an unrelenting overall condition which interferes with individuals' ability to function to their normal capacity" 74. This definition of fatigue incorporates all feelings / degrees of fatigue as well as the impact of fatigue on functions.

Almost half of the patients with COPD experience fatigue every day and nearly $45 \%$ report that fatigue is the worst or one of their worst symptoms 7075 . There seem to be no differences in fatigue between men and women with COPD $6476-78$. Fatigue in patients with COPD is related to self-reported limitations in functional performance $687074-7579$ and is associated with poor health $647580-82$. In one study, fatigue was found to be an independent predictor of perceived health in a 12 month follow-up in patients with COPD, indicating that fatigue has a central role in shaping the global health perception in these patients ${ }^{80}$. More recently, fatigue has been found to predict hospital admission ${ }^{83}$, which underlines that fatigue is a core symptom in this group of patients.

The proposed underlying aetiology of fatigue in chronic illnesses is multifactorial $7284-85$. Factors that are possible contributors to the experience of fatigue in chronic illnesses include loss of aerobic capacity, nutritional deficiencies, muscle wasting, systemic inflammation, anxiety and depression, and insomnia ${ }^{72}$. In patients with COPD it has been widely reported that there is a moderate relationship between fatigue and exercise capacity 49 80-81 86. However, the relationship between fatigue and lung function is ambiguous 4964 68 81-82 86-87 with most studies reporting no correlation between the two 49646886 . Two studies have reported a negative relationship between fatigue and muscle 
strength, and fatigue and lung function in patients with a severe disease ${ }^{81-82}$. None of the mentioned studies have examined the relationship between fatigue and physical capacity in men and women separately.

Although several studies have shown that fatigue in COPD is related to greater limitations in self-reported functional performance 68 70 $74-7579$ the relation between fatigue and PA is unclear. Two recent studies showed a negative relation between fatigue and PA 53 64. In the study by Baghai-Ravary et al. ${ }^{6}$ fatigue remained the only factor significantly associated with time spent outdoors, suggesting fatigue is considerable restrictor of physical activity. One study found fatigue to be one of the correlates to physical activity measured with an activity monitor ${ }^{53}$ while another study did not found a relation between fatigue and physical activity measured with an accelerometer 49. To elucidate the pathway to low PA in COPD we need to understand which factors are important contributors to PA.

There are several questionnaires assessing fatigue in chronic illness, both onedimensional and multidimensional ${ }^{88}$. The one-dimensional questionnaires typically assess the severity of fatigue. The multi-dimensional questionnaires include primarily the severity of fatigue but also frequency and duration and/or the consequences/impact of fatigue on different functions in daily life 88. It is important to distinguish between assessing the symptom itself and the impact of the symptom on different functions ${ }^{89}$. In Figure 2 the different measurable dimensions of fatigue are distinguished. In this thesis the focus was on the experience of fatigue, including the frequency, duration and severity of fatigue. 


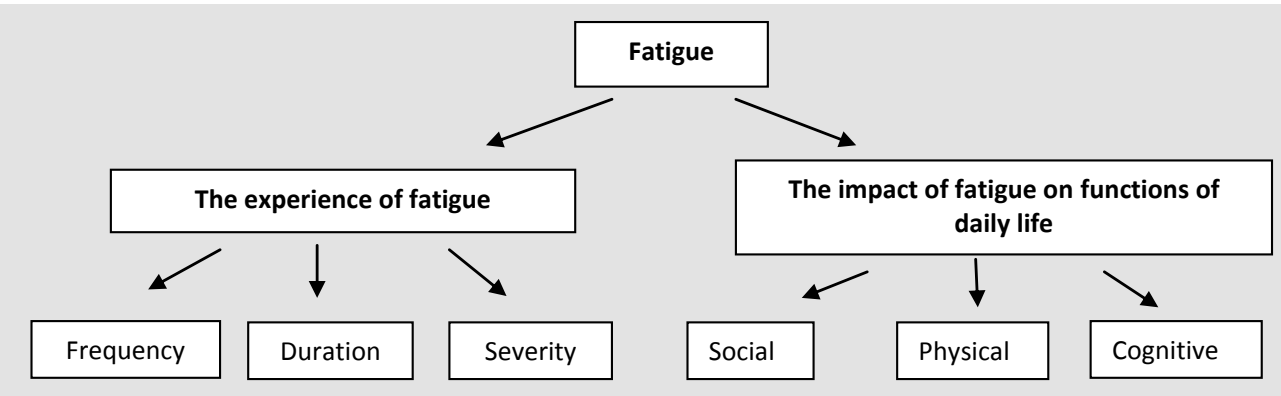

Figure 2. Measurable dimensions of fatigue

\section{Depression and anxiety}

Symptoms of depression are considered as an important systemic manifestations of the disease, which is commonly seen in patient with COPD 16. Depressive symptoms are related to poorer exercise capacity 90 and are associated with a higher risk of drop out from pulmonary rehabilitation maintenance programs ${ }^{91}$. The latter might be indicative of a negative effect of depression on PA. Women with COPD suffer more often from symptoms of depression and anxiety ${ }^{92-93}$.

\section{Symptom burden}

Except for the above mentioned symptoms, patients with COPD experience several other symptoms ${ }^{68}{ }^{94}$. Patients with severe COPD report on average 10 to 11 symptoms ${ }^{7194}$. In patients with COPD, the total symptom burden, i.e. the multi-dimensional characteristics (frequency, severity and distress) of concurrent symptoms, has been found to be comparable as to that of patients with advanced cancer, but the patients with COPD have much longer survival ${ }^{95}$. Little is known about how symptom burden affects PA. 


\section{Disease severity}

Although COPD primarily is a lung disease, because of the fact of its considerable systemic consequences and the fact that lung-function alone is inadequate for staging the disease ${ }^{7}$ a multi-dimensional disease severity index was developed, the BODE index ${ }^{96}$. The index includes the Body mass index, the degree of air-way Obstruction (as measured by the $\mathrm{FEV}_{1} \%$ of predicted), the degree of Dyspnoea (as measured by the Medical Research Council dyspnoea scale) and Exercise capacity (as measured by the 6-minute walk distance). Although they are interrelated, these four variables were chosen as they signify different aspects of the pathophysiology of COPD and are all independent predictors of mortality ${ }^{97}$. The BODE index is a 10-point scale in which higher scores means a higher risk of death. The BODE index scoring is outlined in Table 1.

Table 1. The multidimensional grading of the disease severity in the BODE Index

Variables and point values used for the calculation of the Body Mass Index Degree of Airflow Obstruction, Dyspnoea, and Exercise Capacity (BODE) Index.

\begin{tabular}{|c|c|c|c|c|}
\hline \multirow{2}{*}{$\begin{array}{l}\text { Variables } \\
\text { Score }\end{array}$} & \multicolumn{4}{|c|}{ BODE index score } \\
\hline & 0 & 1 & 2 & 3 \\
\hline $\mathrm{FEV}_{1} \%$ predicted & $\geq 65$ & $50-64$ & $36-49$ & $\leq 35$ \\
\hline 6 minute walk distance (meter) & $\geq 350$ & $250-349$ & $150-249$ & $\leq 149$ \\
\hline MRC dyspnoea score & $0-1$ & 2 & 3 & 4 \\
\hline Body-mass index (BMI) & $>21$ & $\leq 21$ & & \\
\hline \multicolumn{5}{|c|}{$\begin{array}{l}\text { Notes: The total possible values range from } 0 \text { to } 10 \text {. Higher scores = more } \\
\text { serious disease. MRC; Medical Research Council score } 0-4 \text { the higher the } \\
\text { score, the worse the dyspnoea. Body Mass Index = weight }(\mathrm{kg}) / \text { height } \\
(\mathrm{m})^{2} \text {. }\end{array}$} \\
\hline
\end{tabular}

Although, the BODE index is a better predictor of mortality than lung function alone in both men and women ${ }^{98}$ the contribution of each component to the BODE index differs between the sexes ${ }^{99}$ and the mortality rate is higher in 
men than in women having comparable BODE index scores ${ }^{98}$. In addition, and despite the fact that the BODE index includes the symptom of dyspnoea the relation between BODE index and fatigue is inconsistent ${ }^{78} 80$.

Symptoms, including not only the symptom of dyspnoea, and exacerbation rate have, in the updated strategy document from GOLD, been given a central role in the assessment and management of the disease, and this may be of more importance in future classifications systems of the disease severity ${ }^{7}$. In this thesis, the severity of the disease refers to the BODE index score ${ }^{96}$.

\section{Body composition}

Malnutrition in sense of weight loss and wasting of muscle mass are significant manifestations in COPD ${ }^{16}$. Low fat-free mass (muscle mass) in COPD is related to muscle strength, and the level of PA ${ }^{100}$, and a body mass index below 21 has been shown to be related to worse prognosis ${ }^{96}$. Malnutrition includes not only under-nutrition but also overweight and obesity as defined by BMI ( $>25$ and $>30 \mathrm{~kg} / \mathrm{m}^{2}$ respectively). Studies have shown that only a minority of patients with COPD are underweight; instead the majority of the patients are overweight or obese ${ }^{101-102}$. Obesity might restrict both physical capacity and PA in patients with COPD. In one study including 355 patients with COPD with a mean $\mathrm{FEV}_{1} \%$ of predicted of 58 , only $3 \%$ were under-weight compared to $20 \%$ of who were overweight and $54 \%$ who were obese ${ }^{101}$. The same study found that the accumulation of fat mass was associated with low physical capacity (assessed by chair stands, balance, and walking distance) and not the reduction of muscle mass ${ }^{101}$. Monteira et al. 102 showed that obese patients with COPD were more physically inactive than normal weight patients and that fat mass but not fat-free mass correlated with PA. The independent association of fat mass with PA was not evaluated. It is interesting to evaluate the relation between fat mass and PA as over-nutrition can be addressed by diet. 


\section{Rationale of this thesis}

COPD is a public health issue and a major cause of mortality and morbidity among adults ${ }^{8}$. COPD is a disease with several systemic consequences ${ }^{16}$ and is the chronic illness that impacts the most on health related quality of life ${ }^{40103}$. Physical inactivity in COPD is related to increased risk of hospital admission and mortality ${ }^{44-45}$. A problem is that the reduction in physical activity starts early in the disease ${ }^{42-43}$. The disease is associated with several symptoms, with the two most common being dyspnoea and experience of fatigue. Fatigue is related to functional limitations ${ }^{75}$, worse physical capacity ${ }^{80-82} 86$, and worse health 7580 , and was recently found to predict hospital admission ${ }^{83}$. The relationship between fatigue and physical activity remains unclear 644953 . Understanding the factors associated with low physical activity is essential if health care professional are to develop and offer adequate support and rehabilitation. Although several factors are potential restrictors of physical activity 104 one hypothesis in this thesis was that the extent to which the symptom of fatigue is experienced is important, and that the more constant the experience of severe fatigue, the greater the impact on the level of PA.

With increasing prevalence of COPD among women there is a correspondingly increasing knowledge of differences in the clinical presentation of the disease between the sexes ${ }^{105}$. Although the experience of fatigue seems to be similar in men and women with COPD ${ }^{77}$ the findings that women have worse exercise capacity ${ }^{33-34}$ and are more prone to impaired thigh muscle function than men ${ }^{32}$ suggests a stronger relation between fatigue and factors of physical capacity. However, there seem to be differences between men and women as regards the factors associated with dyspnoea ${ }^{6}$ 106 and this raises the question of whether there are differences between the sexes in the relationship between fatigue and factors of physical capacity and disease severity. If such differences exist, this may have clinical implications for improving strategies to relieve fatigue in this group of patients. 


\section{AIMS}

The overall aim of this thesis was to examine the relationship between two dimensions of physical function (physical activity and physical capacity) and the experience of fatigue in patients with COPD.

The specific aims were

- To describe the level of physical activity in patients with COPD.

- To explore factors associated with low physical activity, with a focus on fatigue, symptom burden and body composition.

- To examine the experience of fatigue and its relationship to factors of physical capacity and disease severity in men and women with COPD. 


\section{PATIENTS AND METHODS}

\section{Patients}

One hundred and twenty-one patients were included in a cross-sectional study. The patients were recruited from two outpatient clinics at one university hospital and one county hospital. Patients were recruited consecutively following their first registered visit to the clinic the year before the study started. Inclusion criteria were a diagnosis of COPD and a postbronchodilator forced expiratory volume in one second to forced vital capacity ratio $\left(\mathrm{FEV}_{1} / \mathrm{FVC}\right)<0.70$. In addition, the patients had to be in a clinically stable condition with no change in medication in the past four weeks. Patients were excluded if they had any other lung disease, cancer in the past five years, known inflammatory disease (e.g. rheumatoid arthritis, inflammatory bowel disease), multiple sclerosis, stroke, severe ischemic heart disease, severe kidney dysfunction, insulin-dependent diabetes or psychosocial or physical difficulties that might interfere with the assessments. In total, 198 patients who had visited the outpatient clinics the previous year were invited by letter to participate. One hundred and twenty-one patients were scheduled for the assessment. Seventy-six patients did not want to participate, or were excluded in accordance with the exclusion criteria, or could not be reached, and one did not turn up at the appointment. A flow chart showing recruitment and inclusion is shown in Figure 3. The first included 20 patients not assessed for physical activity were younger 62.2 (SD 3.7) vs. 67.9 (SD 7.3) years $(p<0.001)$ and were more often still smoking 11 out of 20 vs. 23 out of $101(p<0.01)$. There were no differences in age or sex-distribution between participating patients $(\mathrm{n}=121)$ and non-participating patients $(\mathrm{n}=77)$. 

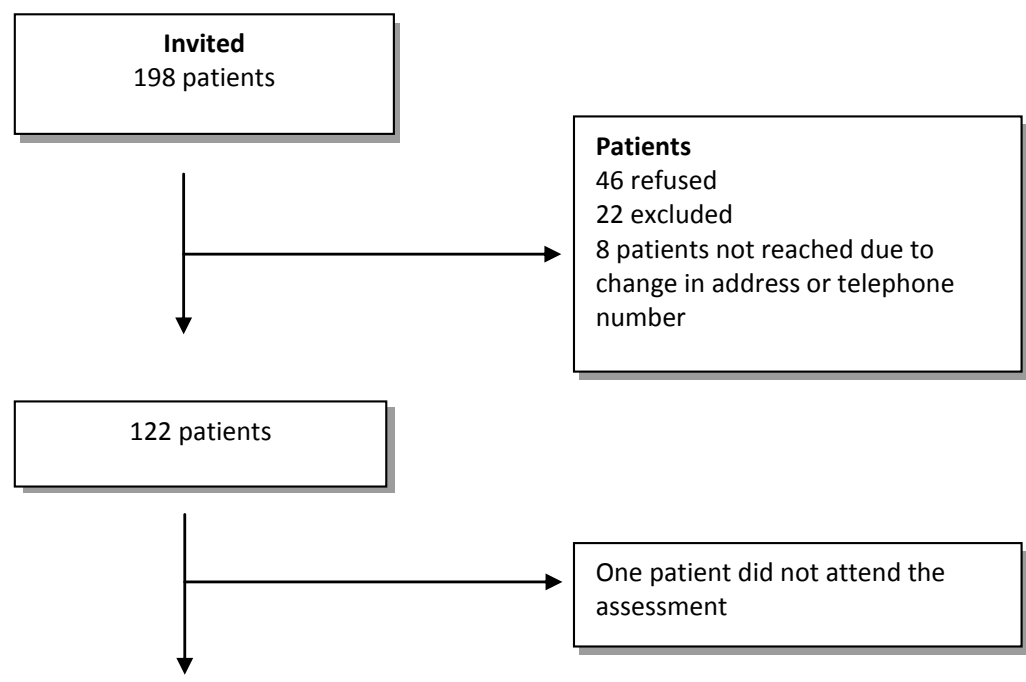

Included in paper II

121 patients

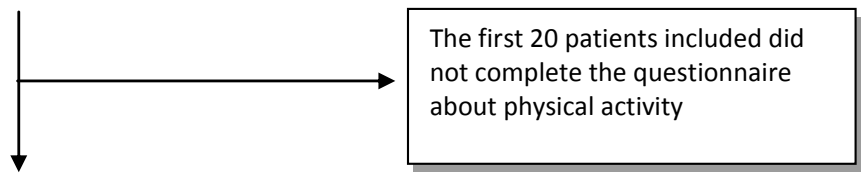

Included in paper I

101 patients

Figure 3. Flow chart of recruitment and inclusion of patients with COPD

\section{Measurements}

Variables included in the study and the instruments used to measure them are presented in Table 2. 
Table 2. Overview of variables and instrument used in the studies

\begin{tabular}{|c|c|c|c|}
\hline Variable & Instrument & $\begin{array}{l}\text { Paper } \\
\mathrm{I}\end{array}$ & $\begin{array}{c}\text { Paper } \\
\text { II }\end{array}$ \\
\hline \multicolumn{4}{|l|}{ PHYSICAL FUNCTION } \\
\hline \multicolumn{4}{|l|}{ Physical capacity } \\
\hline Lung function & Dynamic lung function test ${ }^{107}$ & $x$ & $x$ \\
\hline Exercise capacity & The 6-minute walk distance test ${ }^{108}$ & $x$ & $x$ \\
\hline $\begin{array}{l}\text { Leg fatigue immediately } \\
\text { after the exercise capacity test. }\end{array}$ & The Borg Category Ratio-10 scale ${ }^{109}$ & & $x$ \\
\hline $\begin{array}{l}\text { Dyspnoea immediately } \\
\text { after the exercise capacity test. }\end{array}$ & The Borg Category Ratio-10 scale ${ }^{109}$ & & $\mathrm{x}$ \\
\hline $\begin{array}{l}\text { Breathing frequency immediately } \\
\text { after the exercise capacity test }\end{array}$ & Number of breaths in one minute & & $\mathrm{x}$ \\
\hline $\begin{array}{l}\text { Oxygen saturation immediately } \\
\text { after the exercise capacity test }\end{array}$ & Pulsoximeter & & $\mathrm{x}$ \\
\hline Grip strength & The Grippit ${ }^{\circledR 110}$ & $x$ & $x$ \\
\hline Lower limb muscle strength. & Timed Stands Test ${ }^{111}$ & $x$ & $x$ \\
\hline Physical activity & International Physical Activity Questionnaire-Short ${ }^{112}$ & $x$ & \\
\hline \multicolumn{4}{|l|}{ SYMPTOMS AND SYMPTOM BURDEN } \\
\hline Dimensions of experience of fatigue & $\begin{array}{l}\text { Structured questions about frequency, duration and } \\
\text { severity }^{70}\end{array}$ & $\mathrm{x}$ & \\
\hline Presence or absence of fatigue & Dichotomy: experience or no experience of fatigue & & $x$ \\
\hline Moderate and severe fatigue & Sum of the scores for frequency, duration and severity & $x$ & \\
\hline Dyspnoea & Medical Research Council-dyspnoea scale $\mathrm{e}^{113}$ & $\mathrm{x}$ & $x$ \\
\hline Anxiety and Depression & The Hospital Anxiety and Depression Scale ${ }^{114}$ & $\mathrm{x}$ & \\
\hline Symptom burden & The Memorial Symptom Assessment Scale ${ }^{115}$ & $x$ & \\
\hline \multicolumn{4}{|l|}{ BODY MEASUREMENTS } \\
\hline Body height, $\mathrm{cm}$ & Wall mounted stadiometer & $x$ & $x$ \\
\hline Body weight, kg & SECA scale Class (iii) & $x$ & $x$ \\
\hline Body Mass Index & $\mathrm{kg} / \mathrm{m}^{2}$ & $x$ & $x$ \\
\hline Body composition & Bio-impedance analysis ${ }^{116}$ & $x$ & \\
\hline Fat-free Mass Index & Fat-free mass $\mathrm{kg} / \mathrm{m}^{2}$ & & \\
\hline Fat Mass Index & Fat mass $\mathrm{kg} / \mathrm{m}^{2}$ & & \\
\hline DISEASE SEVERITY & $\begin{array}{l}\text { The BODE index (B; body mass index, O; airway } \\
\text { obstruction, D; dyspnoea, E; exercise capacity) }^{96}\end{array}$ & & $x$ \\
\hline SYSTEMIC INFLAMMATION & & $x$ & \\
\hline C-reactive protein & Venous blood sample & $x$ & \\
\hline Interleukin-6 & Venous blood sample & $x$ & \\
\hline \multicolumn{4}{|l|}{ HEALTH STATUS } \\
\hline Mental and Emotional Health & $\begin{array}{l}\text { Brief Health information from the International } \\
\text { Classification of Disability and function- } \\
\text { (ICF)checklist }{ }^{117}\end{array}$ & $x$ & $\mathrm{x}$ \\
\hline Physical Health & Brief Health information from the ICF-checklist ${ }^{117}$ & $x$ & $x$ \\
\hline
\end{tabular}

\section{Physical function}

Physical function included assessments of physical activity (PA) and of physical capacity; lung function, exercise capacity (including measures of 
saturation, perceived dyspnoea, leg fatigue and breathing frequency) and muscle strength in both the upper and lower extremities (Table 2).

\section{Physical activity}

Physical activity was assessed with the International Physical Activity Questionnaire - Short (IPAQ-S) ${ }^{112}{ }^{118}$. The IPAQ measures, in minutes, selfreported time engaged in walking, moderate physical activity and vigorous physical activity, and the daily average time spent sitting in the previous seven days. All types of physical activity are included but only activity sessions lasting 10 minutes or more are counted. The number of days and the daily average amount of time spent walking, and doing moderate or vigorous activity are asked for, e.g. "During the last seven days on how many days did you walk for at least 10 minutes at a time? This question is followed by a question about how much time was usually spent in the activity on those days. The total amount of time spent is calculated by multiplying the number of days with the number of minutes in each category of physical activity. If the reported minutes for walking, moderate or vigorous activities exceeded 180 $\mathrm{min} /$ day, data were truncated to be equal to $180 \mathrm{~min} /$ day in accordance with the truncation of data rules ${ }^{119}$. The sum of all minutes in each activity item was multiplied by predefined metabolic equivalents (METs) for the different activities. A walking minute equals 3.3 METs, a moderate activity minute equals 4.0 METs and a vigorous minute equals 8.0 METs. MET-minutes/week (days*time*MET value) in each activity category and total MET-min/week were calculated; IPAQwalk MET-min/week, IPAQmoderate MET-min/week; IPAQvigorous MET-min/week and IPAQtotal MET-min/week.

The patients were categorised as having a high, moderate or low level of physical activity according to the IPAQ scoring protocol ${ }^{119}$. According to the IPAQ scoring protocol ${ }^{119}$ moderate physical activity level is defined as any of the following three criteria: three or more days of vigorous activity of at least 20 minutes per day OR five or more days of moderate activity or walking of at least 30 minutes per day OR five or more days of any activity accumulating at least 600 MET-min/week. High physical activity level is defined as vigorous 
activity on at least three days and accumulating at least 1500 MET-min/week OR seven or more days in any combination of walking, moderate or and vigorous activities achieving minimum of at least 3000 MET-min/week.

The test-retest reliability of IPAQ-S from five different sites was found to be reliable for total PA $\left(r_{\mathrm{s}}=0.66-0.89\right)^{112}$. Criterion validity has been found to be acceptable ( $r=0.34$ for total PA) compared to the accelerometer-assessed PA with Swedish adults 118 and the IPAQ-S has previously been used on patients with COPD ${ }^{54}$.

As the IPAQ-S is not well established in patients with COPD, convergent validity was established in the present study by a Spearman correlation analysis between the IPAQ- $S$ and accelerometer-assessed physical activity. Forty randomly selected patients among the patients recruited at the university hospital additionally carried a wrist worn accelerometer, the Actiwatch-L @ Uniaxial Accelerometer (Cambridge Neurotechnology, Cambridge, UK). The Actiwatch-L was positioned on the non-dominant wrist for the same week in which the IPAQ-S assessment was carried out. The

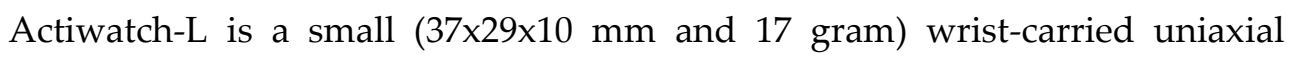
accelerometer. The accelerometer senses 32 times per second and the signal with the highest amplitude is recorded and denoted as an activity count. This represents the peak intensity of movement in that second. The peak intensity values, i.e. counts, are summed into an epoch. In this study, the epoch-time was one minute. Data from one patient's accelerometer was not valid and therefore the average day-activity counts/min over five days including two weekend days in 39 patients were used to ensure convergent validity of the IPAQ-S. The Spearman's correlations coefficient between IPAQtotal MET$\mathrm{min} /$ week and average counts/min was $\mathrm{r}_{\mathrm{s}}=0.546(\mathrm{p}<0.001)$ and between IPAQmoderate MET-min/week and average counts/min, $\mathrm{r}_{\mathrm{s}}=0.571(\mathrm{p}<0.001)$. There were no statistically significant correlations between the average counts/min and the IPAQwalk MET-min/week or IPAQvigorous MET $\mathrm{min} /$ week. 


\section{Physical capacity}

Lung function was assessed with a dynamic spirometry (Master Scope ${ }^{\circledR}$ Jaeger, Germany) post bronchodilation ( $0.6 \mathrm{mg}$ of salbutamol metered-dose aerosol + spacer) (FEV 1 and FVC) in accordance with the ATS/ERS standardisation ${ }^{107}$. Normative values from Hedenstrom et al. ${ }^{120-121}$ were used. The severity of the airflow limitation was, based on the post-bronchodilator $\mathrm{FEV}_{1}$ percentage of predicted, classified into the four GOLD grades: GOLD 1, mild $=>80 \%$ of predicted; GOLD 2, moderate $=50-79 \%$ of predicted; GOLD 3, severe $=30-49 \%$ of predicted and GOLD 4 , very severe $=<30 \%$ of predicted ${ }^{7}$.

Exercise capacity was assessed with duplicate 6-minute walk distance tests (6MWD) in accordance with the ATS guidelines ${ }^{108}$. The longest 6MWD was used in the analysis. For reference values the equation developed by Troosters et al. was used ${ }^{122}$. In addition, during the test, oxygen saturation was measured with a pulsoximeter (Pulsoximeter Nonin, Model 2500, Plymouth, USA) and perceived dyspnoea and leg fatigue before and immediately after the test were scored using the Borg Category Ratio-10 scale ${ }^{109}$. The number of breaths during one minute, i.e. breathing frequency was registered before and after the 6MWD.

The muscle strength of the upper extremity was measured in the dominant hand using Grippit ${ }^{\circledR}$ (AB Detektor, Göteborg, Sweden). Grip force was registered for 10 seconds and expressed in Newton $(\mathrm{N})$. The peak value from three trials was used in the analyses. This method is considered to be reliable and valid, $r_{s}=0.93$ in healthy women and $r_{s}=0.89$ in women with rheumatoid arthritis ${ }^{110}$. The muscle strength of the lower extremities was assessed with the timed-stands test (TST) ${ }^{123}$. The test measures the time in seconds (to the nearest 0.1 second) for 10 stand-ups from a chair to a standardised height (45 centimetres). The test is considered to be reliable (average coefficient of variation [the ratio SD / mean] of $6.8 \%$ ) and valid ${ }^{111}$. 


\section{Symptoms and symptom burden}

\section{Experience of fatigue}

The experience of fatigue was assessed with three structured questions covering the frequency, duration and severity of fatigue the previous month. These questions have previously been used with Swedish patients with $\mathrm{COPD}^{70} 7^{124}$. The scoring of these questions is outlined in Table 3 . The frequency of fatigue in the past month was scored as $0=$ not a problem, $1=1-7$ days/month, 2=8-14 days/month, 3=15-21 days/month or 4=22-30 days/month or every day of the month; the duration of fatigue as $0=$ no experience, $1=$ less than 6 hours/day, 2=6 to12 hours/day or 3= more than 12 hours/day; and the severity of fatigue as $0=$ not a problem, $1=$ one of my less severe symptoms or $2=$ one of my worst symptoms. Cronbach's alpha for the three questions was 0.79 in the present study. The fatigue sum score for frequency, duration and severity (range 0-9) was calculated. Convergent validity was established with Spearman's correlation analysis between fatigue sum score and the total score of one item included in the Memorial Symptom Assessment Scale 115 measuring the frequency, severity and distress due to lack of energy (score range $2-12)$, in 111 patients, $r_{s}=0.658(\mathrm{p}<0.001)$.

The patients were classified as having no fatigue, moderate fatigue or severe fatigue. 'No fatigue' was defined as the absence of experience of fatigue in frequency, duration and severity the previous month (light grey scores in Table 3). 'Severe fatigue' was defined as a frequency of 15 days or more in the past month and a duration of six hours or more each time and fatigue rated as a severe problem (dark grey scores in Table 3). Any fatigue not fulfilling the criteria for severe fatigue was defined as moderate fatigue. The experience of fatigue was dichotomised; $1=$ presence of fatigue (fatigue sum score $=1-9$ ) (medium grey area in Table 3 ) and $0=$ absence of fatigue (fatigue sum score $=0)$. 
Table 3. The experience of fatigue in the previous month

\begin{tabular}{|c|c|c|c|c|c|}
\hline & \multicolumn{5}{|c|}{ Scoring } \\
\hline & 0 & 1 & 2 & 3 & 4 \\
\hline $\begin{array}{l}\text { Frequency of } \\
\text { fatigue }\end{array}$ & not a problem & $\begin{array}{l}1-7 \\
\text { days/month }\end{array}$ & $\begin{array}{l}8-14 \\
\text { days/month }\end{array}$ & $\begin{array}{l}15-21 \\
\text { days/month }\end{array}$ & $\begin{array}{l}22-30 \\
\text { days/month or } \\
\text { every day of the } \\
\text { month }\end{array}$ \\
\hline Duration of fatigue & no experience & $\begin{array}{l}\text { less than } 6 \\
\text { hours/day }\end{array}$ & $\begin{array}{l}6-12 \\
\text { hours/day }\end{array}$ & $\begin{array}{l}\text { more than } 12 \\
\text { hours/day }\end{array}$ & \\
\hline Severity of fatigue & not a problem & $\begin{array}{l}\text { one of my less } \\
\text { severe } \\
\text { problems }\end{array}$ & $\begin{array}{l}\text { one of my } \\
\text { worst } \\
\text { symptoms }\end{array}$ & & \\
\hline $\begin{array}{l}\text { Fatigue sum-score, } \\
\text { range } 0-9\end{array}$ & $\begin{array}{l}\text { no experience } \\
\text { / absence of } \\
\text { fatigue }\end{array}$ & \multicolumn{4}{|c|}{$\begin{array}{l}\text { Presence of fatigue; the sum of the frequency, duration and severity } \\
\text { scores, possible range } 1-9 .\end{array}$} \\
\hline
\end{tabular}

$\square=$ no experience of fatigue/absence of fatigue, $\square$ = presence of any experience of fatigue, $\square=$ severe fatigue

\section{Other symptoms and symptom burden}

Dyspnoea-related disability was assessed by the Medical Research Council (MRC) dyspnoea scale ${ }^{113}$. The scale consists of five statements of different degrees of dyspnoea during certain activities. The score range between $0-4$ with 0 representing breathlessness with strenuous activities and 4 representing breathlessness when putting on clothes and/or too breathless to leave the house.

Symptoms of anxiety and depression were assessed by the Swedish validated version of the Hospital Anxiety and Depression Scale (HADS) ${ }^{114}$. The questionnaire comprises 14 items; seven items measure anxiety and seven items measure depression. The total score for each dimension ranges from 0 to 21 , with the higher score indicating higher symptom levels.

Symptom burden was assessed with The Memorial Symptom Assessment Scale (MSAS) assessing 32 symptoms ${ }^{115}$. The MSAS has previously been used in patients with COPD ${ }^{94-95}$. The MSAS evaluates the frequency (rarely, occasionally, frequently or almost constantly) of 24 symptoms and the severity (slight, moderate, severe or very severe) and distress (not at all, a little bit, 
somewhat, quite a bit or very much) of all 32 symptoms during the past week. It then yields one total symptom burden score (TMSAS) and two subscales of symptom burden, the Physical Symptom Subscale score (MSAS-PHYS), and the Psychological Symptom Subscale score (MSAS-PSYCH). The TMSAS is the average score of frequency, severity and distress of all the 32 symptoms. The MSAS-PHYS is the average score of 12 physical symptoms (lack of appetite, lack of energy, pain, feeling drowsy, constipation, dry mouth, nausea, vomiting, and change in taste, weight loss, feeling bloated, and dizziness). The MSAS-PSYCH is the average score of six psychological symptoms (worrying, feeling sad, feeling nervous, difficulty sleeping, feeling irritable, and difficulty concentrating). All MSAS scores range from 0-4 and the higher the score the greater the symptom burden. The Cronbach's alpha coefficient in the present study was 0.84 for TMSAS, 0.67 for MSAS-PHYS and 0.74 for MSAS-PSYCH.

\section{Body Measurements}

All patients were checked for height $(\mathrm{cm})$ to the nearest $0.5 \mathrm{~cm}$ using a wallmounted stadiometer, and for weight $(\mathrm{kg})$ to the nearest $0.1 \mathrm{~kg}$ without shoes and with light clothing (SECA scale Class (iii) model 701 and 959; SECA GmbH \& Co. KG, Hamburg, Germany). BMI was calculated = weight (kg)/ height $\left(\mathrm{m}^{2}\right)$. All patients were categorized into four BMI groups: $<21=$ underweight; $21-24.9$ = normal range; $25-29.9$ = overweight; or $\geq 30$ = obesity 125. One hundred and one patients also underwent a whole-body bioimpedance analysis (BIA-103, RJL systems, Detroit) ${ }^{116}$. The analysis was made in the morning on the right side with the patient in a supine position, after one night of fasting. Fat-free mass and fat mass were derived from the bioelectrical impedance analysis and a disease-specific equation was used to calculate fat-free mass (FFM) $[-6.06+$ (height $\times 0.283)+($ weight $\times 0.207)$ (resistance $\times 0.024)+\operatorname{sex}($ males $=1$, females $=0 \times 4.036)]{ }^{126}$. The principal of bioelectrical impedance is based on the conductance of an electrical current through body fluids. Conductivity is higher in FFM than in fat mass (FM) as the former contains all body fluids and electrolytes. Theoretically is FFM linearly related to height ${ }^{2} /$ body resistance ${ }^{127}$. The fat-free mass index (FFMI) was defined as FFM $(\mathrm{kg})$ divided by the square of height $\left(\mathrm{m}^{2}\right)$ and a similar 
equation was used to calculate the fat mass index (FMI) [FM $(\mathrm{kg})$ divided by the square of height $\left.\left(\mathrm{m}^{2}\right)\right]^{128}$.

\section{Disease severity}

Disease severity was determined according to the criteria of the multidimensional grading system, the BODE index ${ }^{96}$. The BODE index includes $\mathrm{BMI}$, airway obstruction ( $\mathrm{FEV}_{1} \%$ predicted), dyspnoea measured by the MRC-dyspnoea scale ${ }^{113}$, and exercise capacity measured as the 6MWD. The BODE index ranges between 0 and 10, with a higher score indicating a more serious disease ${ }^{96}$.

\section{Systemic inflammation}

To assess markers of systemic inflammation a blood sample was obtained from each of the 101 patients. A registered nurse collected a fasting blood sample in the morning $(08.00-10.00)$ and plasma was obtained by centrifugation at $1500 \times \mathrm{g}$ for 15 minutes at room temperature. The samples were stored at $-70{ }^{\circ} \mathrm{C}$ until analysis. The high-sensitivity $\mathrm{C}$-reactive protein (CRP) and interleukin 6 (Il-6) served as markers of systemic inflammation.

\section{Perception of general health}

Two questions from the Brief Health Information in the International Classification of Functioning, Disability and Health check list (ICF-checklist) were used which asked about perceived mental and emotional health as well as physical health in the past month, rated on a five point scale from $1=$ very bad health to $5=$ very good health ${ }^{117}$. 


\section{Demographic data}

Structured questionnaires covered demographic data (age, marital status, educational level and employment), smoking history, the number of exacerbations, defined as a worsening of respiratory symptoms that required change in the COPD-related medication in the last six months, and engagement in any physical training or rehabilitation.

\section{Procedure}

All patients were informed about the study and invited to participate by letter and were contacted by telephone approximately a week later to provide them with additional information and to update their current health status. Those who fulfilled the inclusion criteria and gave verbal informed consent were scheduled for an appointment at the outpatient clinic. Prior to the appointment questions were sent to the patients covering demographics, smoking history, the number of exacerbations, and engagement in any physical training or rehabilitation. Questionnaires covering the symptom of fatigue and health status were also included. The participants were instructed to answer these questions and questionnaires the day before the appointment. Their responses were checked at the appointment to avoid missing answers. All other assessments, including answering the questionnaire about PA and anxiety and depression, were performed at the outpatient clinics in the morning in a standardised order and with an appropriate amount of time between the assessments of physical capacity. The accelerometer that was carried by 40 patients was personally distributed to patients by the author.

All data were collected between January 2007 and September 2009. 


\section{Ethical considerations}

The study was performed in accordance with the ethical principles for medical research involving human subjects outlined in the Declaration of Helsinki, and was approved by the regional ethical review board, Linköping, Sweden (Dnr M 121-06 and 21-07). All patients gave informed consent prior to any studyrelated procedures taking place.

\section{Statistical Analysis}

Descriptive statistics were used and normally distributed data were presented as mean and standard deviation, m (SD), and skewed data as median and 25th-75th percentile, md (Q1-3). Analysis was conducted of two groups, i.e. men and woman and between patients with and without fatigue. The Chisquare and Fisher's exact test was used for categorical variables, and a twosided independent sample t-test for continuous variables, while the MannWhitney U-test was used for ordinal variables and variables that were not normally distributed. For comparison of more than two groups the One-Way ANOVA was used for continuous variables with normal distribution and the Kruskal-Wallis test for ordinal and not normally distributed continuous variables. The Chi-square test was used for categorical variables. With the ANOVA a Bonferroni correction was used for post hoc analysis and a MannWhitney $U$-test when the Kruskal-Wallis test was used with a corrected pvalue $\leq 0.016$ that was considered significant.

To explore factors independently associated to low PA, a backward multiple logistic regression analysis was used. The variables included in the analysis were the variables that were significantly correlated with PA level, with a pvalue of $\leq 0.15$. The dependent variable PA was dichotomised; $1=$ low PA and $0=$ moderate and high PA. The regression analysis was adjusted for age; sex $(0=$ women, $1=$ men $)$, and smoking $(0=$ not currently smoking, $1=$ currently smoking). 
To address the third research question: "to examine experience of fatigue and its relationship to factors of physical capacity and disease severity in men and women with COPD", fatigue as the dependent variable was dichotomised and coded as $1=$ presence of fatigue or $0=$ absence of fatigue. Partial correlation analysis adjusted for sex and age was performed to investigate the relationship between the presence or absence of fatigue and the variables of physical capacity ( $\mathrm{FEV}_{1} \%$ pred., $\mathrm{FVC} \%$ pred., 6MWD including oxygen saturation, dyspnoea, leg fatigue and breathing frequency immediately after the 6MWD, TST, grip strength and disease severity). Backward logistic regression analyses were performed. Two models were tested, both of which were performed separately in men and women with the purpose of analysing the association of the variables of physical capacity (first model) and disease severity (second model) with the presence and absence of fatigue. The independent variables included in the first model were the variables of physical capacity that significantly correlated $(\mathrm{p}<0.05)$ with fatigue in the partial correlation (FEV $\%$ pred., 6MWD and leg fatigue post-6MWD). In addition, TST and grip strength were inserted, in line with findings in the literature 32 81-82. In the second model, the independent variables were the BODE index and the variables not included in the BODE index (leg fatigue post $6 \mathrm{MWD}, \mathrm{TST}$, grip strength). Both models were adjusted for age and current smoking ( $1=$ current smoker and $0=$ not a current smoker). In additional analysis, we adjusted the models with the variable "mental and emotional health".

For all regression models, independent variables were checked for multicollinearity. Variables with a variance inflation factor (VIF) > 10 were considered problematic ${ }^{129}$. The odds ratio (OR) and $95 \%$ confidence intervals (95\%CI) are presented.

The significance level was set at $\mathrm{p} \leq 0.05$. The data were analysed using SPSS 19 software version (IBM Corp, Armonk NY, USA) 


\section{RESULTS}

Among the 121 patients 54 were men and 67 were women. The mean age was 67 years. Nearly $30 \%$ were current smokers and the mean number of pack years was 33. Most of the patients were in GOLD grade 2 or $3(81 \%)$, (Table 4 ).

Table 4. Background characteristics in 121 patients with stable COPD

\begin{tabular}{|c|c|}
\hline \multicolumn{2}{|l|}{ Background characteristics } \\
\hline Age, m (SD) & $67(7.2)$ \\
\hline Men, n (\%) & $54(45)$ \\
\hline Women, $\mathrm{n}(\%)$ & $67(55)$ \\
\hline Employment, $\mathrm{n}(\%)$ & $24(19)$ \\
\hline Married/cohabiting, (\%) & $87(72.5)$ \\
\hline Education >compulsory school, n (\%) & $33(27)$ \\
\hline Current smokers, n (\%) & $34(28.1)$ \\
\hline Pack-years, m (SD) & $33.3(18.8)$ \\
\hline Current training or rehabilitation, $\mathrm{n}(\%)$ & $28(23)$ \\
\hline \multicolumn{2}{|l|}{ Exacerbation last six month*, n (\%) } \\
\hline 0 & $82(68)$ \\
\hline$\geq 1$ & $37(30.4)$ \\
\hline \multicolumn{2}{|l|}{ GOLD grade } \\
\hline GOLD $1, \geq 80 \%$ predicted $\mathrm{FEV}_{1}$, mild & $6(5)$ \\
\hline GOLD 2, $50-79 \%$ predicted $\mathrm{FEV}_{1}$, moderate & $44(36)$ \\
\hline GOLD 3, $30-49 \%$ predicted $\mathrm{FEV}_{1}$, severe & $55(45)$ \\
\hline GOLD $4,<30 \%$ predicted FEV 1 , very severe & $16(13)$ \\
\hline \multicolumn{2}{|c|}{$\begin{array}{l}\text { Notes: }{ }^{*}=\text { two missing. Definition of abbreviations: } \mathrm{FEV}_{1} \text {; forced } \\
\text { expiratory volume in one second, GOLD; Global initiative for Chronic } \\
\text { Obstructive Lung Disease; MRC, medical research council; Pack years, } \\
\text { number of years smoking multiplied by average number of cigarettes } \\
\text { smoked per day divided by } 20\end{array}$} \\
\hline
\end{tabular}

Lung function was about half of that expected and the 6MWD was $70 \%$ of predicted (Table 5). Women had shorter 6MWD both in absolute values and in percentage of predicted distance compared to men. Women also used more time in the TST and had lower grip strength than men (Table 5). There was no statistically significant difference between men and women regarding BMI 26.2 (SD 5.3) and 27.4 (SD 6.8) respectively but more women were classified as 
obese (BMI >30) than men; $37 \%$ compared to $20 \%$ ( $\mathrm{p}=0.042$ ), and there were significant differences between men and women in FFM index and FM index, with men having a higher FFM index 16.6 (SD 1.5) vs. 15.4 (SD 2.0) $\mathrm{p}<0.001$ and a lower FM index 9.3 (SD 4.2) vs. 11.9 (SD 4.5) ( $\mathrm{p}=0.005)$. There were no significant differences between the sexes regarding the markers of systemic inflammation.

Table 5. Physical capacity and disease severity in total sample and in men and women

\begin{tabular}{|c|c|c|c|c|}
\hline & $\begin{array}{l}\text { All } \\
n=121\end{array}$ & $\begin{array}{l}\text { Men } \\
(n=54)\end{array}$ & $\begin{array}{l}\text { Women } \\
(n=67)\end{array}$ & p-value \\
\hline \multicolumn{5}{|l|}{ Physical capacity } \\
\hline \multicolumn{5}{|l|}{ Lung function } \\
\hline $\mathrm{FEV}_{1} \%$ predicted, $\mathrm{m}(\mathrm{SD})$ & $49.6(16.2)$ & $50.8(16.8)$ & $48.6(15.7)$ & 0.451 \\
\hline FVC\% predicted, m (SD) & $85.7(17.4)$ & $86.6(87.5)$ & 85 (17.9) & 0.615 \\
\hline $\mathrm{FEV} / \mathrm{FVC}, \mathrm{m}(\mathrm{SD})$ & $0.44(0.11)$ & $0.3(0.12)$ & $0.44(0.1)$ & 0.652 \\
\hline \multicolumn{5}{|l|}{ Exercise capacity } \\
\hline 6MWD, m (SD) & $403(137)$ & $432(144)$ & $380(128)$ & 0.039 \\
\hline $6 \mathrm{MWD} \%$ predicted, $\mathrm{m}$ (SD) & $71.5(22.7)$ & $76.9(23.9)$ & $67(20.8)$ & 0.017 \\
\hline TST*, seconds, md (Q1-3) & $24.5(20.0-34.1)$ & $22.4(18.2-33.7)$ & $27.5(22.7-34.3)$ & 0.022 \\
\hline Grip strength*, Newton, md (Q1-3) & $248(176-360)$ & $368(292-442)$ & $190(159-245)$ & $<0.001$ \\
\hline \multicolumn{5}{|l|}{ Disease severity } \\
\hline BODE index, md (Q1-3) & $3(1-5)$ & $3(1-4.25)$ & $3(2-5)$ & 0.243 \\
\hline \multicolumn{5}{|c|}{$\begin{array}{l}\text { P-values were tested by independent sample t-test when a mean (SD) is given or by Mann-Whitney-U test } \\
\text { when the variable is given as a median (Q1-3) and by } \chi 2 \text {-test in variables presented in numbers. Notes: }{ }^{*}=\text { one } \\
\text { - two missing. Definition of abbreviations: } 6 \mathrm{MWD} \text {, six-minute walk distance; BODE index; multidimensional } \\
\text { index (B, body mass index; O, airway obstruction; D, dyspnoea; } \mathrm{E} \text {, exercise capacity), } \mathrm{FEV}_{1} \% \text { predicted, forced } \\
\text { expiratory volume in one second percentage of predicted; FVC\% predicted, forced vital capacity percentage of } \\
\text { predicted; TST, timed stands test. }\end{array}$} \\
\hline
\end{tabular}

\section{Level of physical activity}

Forty-two percent of the patients reported low PA level, 34\% moderate and $24 \%$ high PA levels. The patients spent most time in walking and moderate activities and spent barely any time in vigorous activities (Table 6). The median (Q1-3) for total MET minutes /week was $236(0-550)$ in patients with low PA, 1388 (1040 - 2095) in patients with moderate PA, and 5226 (4039 7751) in patients with high PA (I). Patients with a high PA level spent significantly less time sitting than patients with moderate and low PA levels. 
Median (Q1-3) for minutes/day in low, moderate and high PA levels respectively were $495(420-660), 450(300-600), 300(240-406) \mathrm{p}<0.001$ (I). There were no statistically significant differences between men and women regarding minutes spent walking, or in moderate and vigorous activities, or in the number having low, moderate and high PA.

Table 6. Physical activity in 101 patients with COPD

\begin{tabular}{ll}
\hline & $\begin{array}{l}\text { All } \\
\mathrm{n}=101\end{array}$ \\
\cline { 2 - 2 } $\begin{array}{l}\text { Physical activity } \\
\text { Walking minutes, md (Q1-3) }\end{array}$ & $120(20-315)$ \\
Moderate minutes, md (Q1-3) & $40(0-240)$ \\
Vigorous minutes, md (Q1-3) & $0(0-32)$ \\
Total MET minutes/week, md (Q1-3) & $1074(396-2977)$ \\
Sitting minutes/day, md (Q1-3) \# & $420(300-600)$ \\
PA-level, n (\%) & \\
Low PA & $42(42)$ \\
Moderate PA & $34(34)$ \\
High PA & $25(25)$ \\
\hline Notes: \# = 6 missing. Definition of abbreviations: MET, \\
metabolic equivalent of task
\end{tabular}

\section{Experience of fatigue}

Seventy-four percent of the patients reported the presence of fatigue, $52 \%$ had moderate and $22 \%$ had severe fatigue. There were no differences between men and women in the experience of fatigue (frequency, duration and severity) (II) or in the number classified as having moderate (57\% of the men compared to $48 \%$ of the women) and severe fatigue (18\% of the men compared to $24 \%$ of the women) $\mathrm{p}=0.565$. No statistically significant differences between men and women were found in any of the other symptoms or in the symptom burden. 


\section{Factors associated with low physical activity (paper I)}

More patients with low PA had severe fatigue compared to patients with moderate and high PA (Table 7). Patients with low PA had worse dyspnoea (MRC-dyspnoea scale), a higher burden of physical symptoms (MSAS-PHYS), and worse physical capacity (shorter 6MWD, needed more time in TST, and had lower grip strength) (Table 7). The patients with low PA also reported worse mental and emotional health compared to those with moderate and high PA. The median (Q1-3) mental and emotional health in patients with low PA was $3(3-4)$ compared to $4(3-5)$ and $4(3-4)$ for patients with moderate and high PA respectively $(\mathrm{p}=0.014)$.

There were no statistically significant differences between patients with low, moderate or high PA in FM index or in FFM index (Table 7). In total, 30 patients were obese (BMI>30) and 17 of these had low PA, nine had moderate, and four had high PA. Among the patients with low PA, 41\% were obese compared to $26 \%$ among the patients with moderate PA, and $16 \%$ among those with high PA, but these differences were not statistically significant (I). There were no statistically significant differences between the PA levels in symptoms of anxiety and depression, and markers of systemic inflammation (Table 7), or any of the background characteristics including exacerbation rate.

The logistic regression analysis adjusted for age, sex and current smoking, showed that severe fatigue OR $(95 \% \mathrm{CI}) 5.87$ (1.23 - 28.12), shorter 6MWD OR $(95 \% \mathrm{CI}) 0.99(0.99-1.0)$ and a higher number of pack years OR (95\%CI) 1.04 $(1.01$ - 1.07) were independently associated with low PA level (I). 
Table 7. Differences between COPD patients with low, moderate and high physical activity level

\begin{tabular}{|c|c|c|c|c|}
\hline & $\begin{array}{l}\text { Low PA } \\
n=42\end{array}$ & $\begin{array}{l}\text { Moderate PA } \\
n=34\end{array}$ & $\begin{array}{l}\text { High PA } \\
n=25\end{array}$ & $p$-value \\
\hline \multicolumn{5}{|l|}{ Symptoms } \\
\hline \multicolumn{2}{|l|}{ Classification of fatigue, $n(\%)$} & & & 0.017 \\
\hline No & $9(21)$ & $12(35)$ & $7(28)$ & \\
\hline Moderate & $18(43)$ & $20(59)$ & $15(68)$ & \\
\hline Severe & $15(36)$ & $2(6)$ & $3(12)$ & \\
\hline MRC-dyspnoea $\geq 3$, n (\%) & $22(52)$ & $9(26)$ & $7(28)$ & 0.035 \\
\hline HADS anxiety, md (Q1-3) & $4(1-8)$ & $5(1-8.2)$ & $3(1.5-8)$ & 0.894 \\
\hline HADS depression, md (Q1-3) & $5(2-8.2)$ & $4.5(1-7.2)$ & $4(2-7)$ & 0.439 \\
\hline \multicolumn{5}{|l|}{ Symptom burden } \\
\hline TMSAS, md (Q1-3) & $0.62(0.36-0.89)$ & $0.42(0.24-0.67)$ & $0.52(0.30-0.77)$ & 0.062 \\
\hline MSAS-PHYS, md (Q1-3) & $0.72(0.41-1.02)$ & $0.36(0.14-0.71)^{*}$ & $0.50(0.21-0.74)$ & 0.007 \\
\hline MSAS-PSYCH, md (Q1-3), & $0.50(0.08-1.19)$ & $0.42(0-1.05)$ & $0.50(0.13-1.03)$ & 0.839 \\
\hline \multicolumn{5}{|l|}{ Body composition } \\
\hline FFM index, m (SD) & $15.7(1.9)$ & $16.2(2.1)$ & $16.1(1.5)$ & 0.522 \\
\hline FM index, m (SD) & $10.9(5.0)$ & $11.0(4.5)$ & $9.9(3.7)$ & 0.616 \\
\hline \multicolumn{5}{|l|}{ Physical capacity } \\
\hline 6MWD, m (SD) & 335 (147) & $418(109)^{*}$ & $461(123)^{*}$ & $<0.001$ \\
\hline 6MWD\% of predicted m (SD) & $61(25)$ & $77(19)^{*}$ & $80(20)^{*}$ & 0.001 \\
\hline TST (seconds), md (Q1-3) & $29.3(23.1-38.2)$ & $24.2(20.0-30.3)$ & $21.8(19.2-29.1)^{*}$ & 0.008 \\
\hline Grip strength (N) md (Q1-3) & $228(172-316)$ & $244(170-348)$ & $332(210-430)^{*}$ & 0.032 \\
\hline \multicolumn{5}{|l|}{ Systemic inflammation } \\
\hline CRP, md (Q1-3) & $5.2(2.4-8.2)$ & $5(2.1-7.0)$ & $2.9(1.8-5.8)$ & 0.124 \\
\hline II-6, md (Q1-3) & $3.1(0.9-4.6)$ & $1.9(0.9-5.2)$ & $1.8(0.6-3.2)$ & 0.202 \\
\hline \multicolumn{5}{|c|}{$\begin{array}{l}\text { P-values were tested with one-way ANOVA with a Bonferroni post hoc analysis on normally distributed data, } \\
\text { the Kruskal- Wallis test on data presented as median (Q1-3). A Bonferroni corrected p-value }<0.016 \text { was } \\
\text { considered significant. A } \chi 2 \text {-test was used in variables presented in numbers. *= Significant differences } \\
\text { versus low IPAQ. Definition of abbreviations: MRC; Medical Research Council, N; Newton HADS; hospital } \\
\text { anxiety and depression scale, TMSAS; total memorial symptom assessment score, MSAS-PHYS; memorial } \\
\text { symptom assessment scale-physical, MSAS-PSYCH; memorial symptom assessment scale-psychological, BMI; } \\
\text { body mass index, FM; fat mass, FFM; fat free mass; 6MWD; 6-minute walk distance; TST; timed stands test, } \\
\text { CRP; c-reactive protein, IL-6; interleukin-6 }\end{array}$} \\
\hline
\end{tabular}




\section{The relationship between experience of fatigue and factors of physical capacity and disease severity in men and women (paper II)}

Men experiencing fatigue had worse physical capacity (lung function, exercise capacity and lower limb strength) than men without fatigue. Women experiencing fatigue did not differ significantly in physical capacity compared to women that did not experience fatigue except in that women with fatigue had a significantly higher perception of leg fatigue immediately after the 6MWD (Table 8). The distribution of BMI classes in men and women experiencing fatigue compared with those not experiencing fatigue did not differ significantly. However, all eight men that were underweight (BMI <21) and nine out of 12 underweight women experienced fatigue. Ten out of 11 men that were obese and 20 out of 25 obese women experienced fatigue (II).

To analyse the association between the presence of fatigue and factors of physical capacity and disease severity two models of multiple logistic regressions were tested, both of which were performed separately on men and women. In the first model, independent variables inserted were factors of physical capacity. Significantly associated with the experience of fatigue in the first model were 6MWD in men OR (95\%CI) $0.98(0.97-0.99)$ and 6MWD and leg fatigue after the 6MWD in women OR (95\% CI) $0.99(0.98-1.0)$ and 2.33 $(1.40-3.87)$ respectively (II). In the second model, the BODE index and factors of physical capacity not included in the BODE index were inserted as independent variables. The BODE index was independently associated with fatigue in men OR (95\% CI) 3.71 (1.51 - 9.10) and in women OR (95\% CI) 1.56 (1.07 - 2.24). In women, leg fatigue after the 6MWD also remained independently associated with experience of fatigue OR (95\% CI) 2.19 (1.36 3.51) (II). 


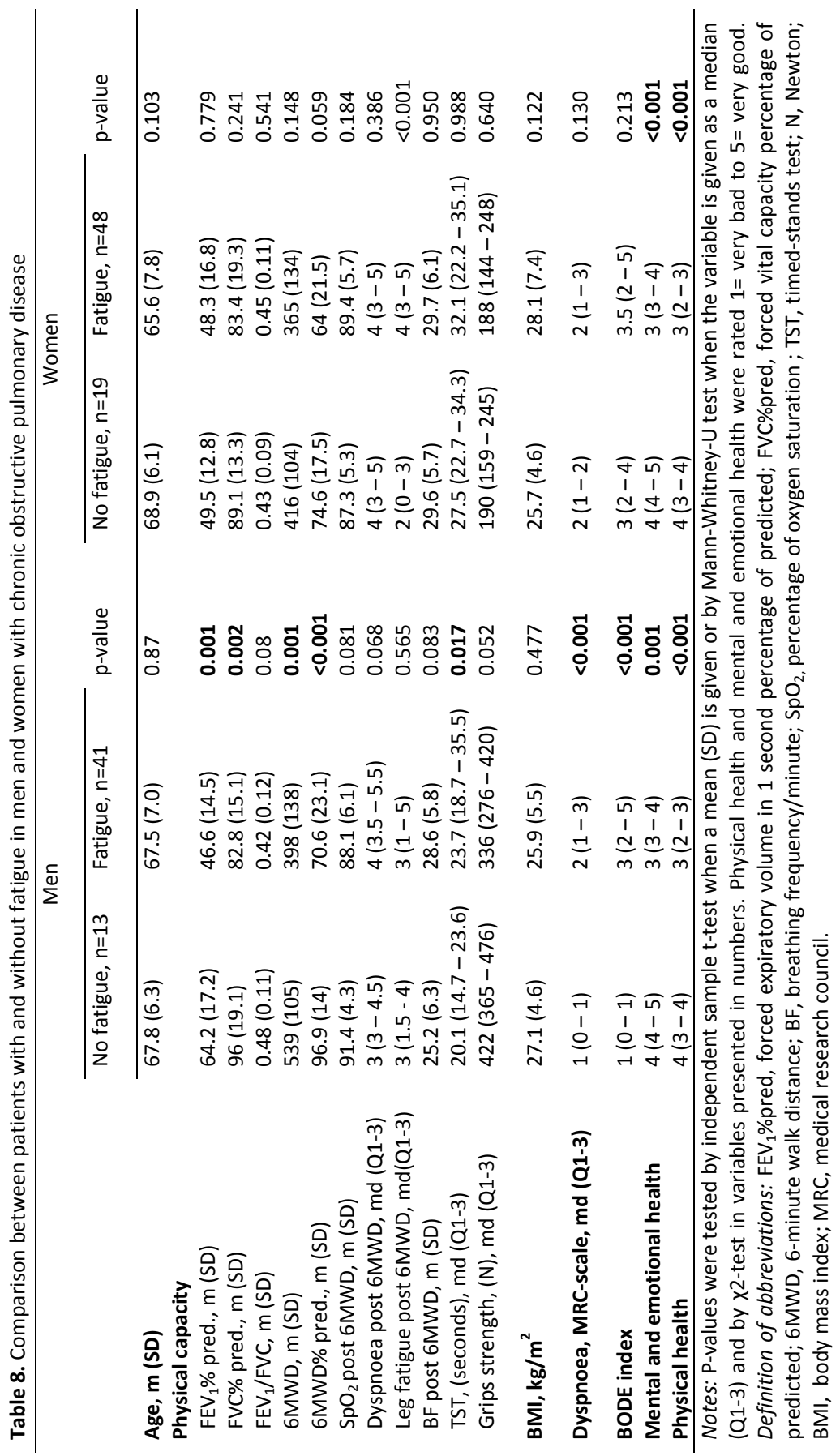




\section{DISCUSSION}

Low physical activity (PA) was common among the patients with stable COPD studied for this thesis. A majority experienced fatigue, with no difference between men and women. Severe fatigue, worse exercise capacity and a higher amount of smoking were independently associated with low PA. Men experiencing fatigue had worse physical capacity (lung function, exercise capacity and muscle strength) and disease severity compared to men without fatigue. Women with fatigue had similar physical capacity and disease severity as women without fatigue, except for a higher leg fatigue. Multiple regression analysis showed that exercise capacity and disease severity were associated with the presence of fatigue in both men and women but in women leg fatigue was strongly associated with experience of fatigue.

\section{Factors associated with low physical activity}

Patients with low PA had a median of 236 METs min /week which is below the recommended accumulation of 500 METs min /week ${ }^{36}$. The proportion of patients having low PA in the present study is somewhat less found by others 53130 . We chose to select patients with stable COPD without any other serious diseases. This could have excluded patients with a greater risk of being physically inactive. Moreover, the patients in the present study had slightly better lung function than the patients in the other studies 53130 . However the proportion with low PA was in line with that found in two studies on patients with COPD from Sweden ${ }^{131-132}$.

Factors independently associated with low PA were severe fatigue, exercise capacity, and a higher amount of smoking. The strongest predictor of low PA was severe fatigue. This was associated with a nearly six fold higher probability of having low PA compared to patients with no experience of fatigue. The association between severe fatigue and low PA is in line with 
other studies showing a relation between fatigue and PA 5364 and corroborates with the findings of Baghai-Ravary et al. ${ }^{64}$ who reported fatigue to be the only factor associated with time spent outdoors. Although no causal relationship can be outlined, our result gives the impression that severe fatigue is a considerable restrictor of PA.

As exercise induced dyspnoea is the most common and characteristic symptom in patients with COPD ${ }^{760}$ we expected that dyspnoea would come out as an associate to low PA. Previous studies have shown conflicting results regarding the relationship between dyspnoea and PA 5065130133 . Katajisto et al. ${ }^{65}$ reported a strong correlation between dyspnoea and PA, while GarciaAymerich et al. ${ }^{50}$ reported a lack of association between dyspnoea and PA even in patients with severe COPD ${ }^{133}$. Depew et al. ${ }^{130}$ reported MRC dyspnoea $\geq 3$ to be the best independent predictor of severe physical inactivity but the study did not evaluate fatigue. We found an association between severe fatigue and low PA but not between severe dyspnoea and low PA. This suggests that PA-induced breathlessness might restrict the intensity of the activity rather than restricting being physically active. It seems that the experience of severe fatigue with high frequency and long duration has a devastating effect on the patient's ability or motivation to adhere to the recommended level of physical activity.

The finding that worse exercise capacity was associated with low PA confirms the sound relation between exercise capacity and PA 41 49-50 53. Pulmonary rehabilitation including exercise training has been shown to increase exercise capacity ${ }^{134}$ but the effect of pulmonary rehabilitation on physical activity seems to be small ${ }^{135}$. A recent study showed that pulmonary rehabilitation improved different dimensions of fatigue ${ }^{136}$. However, the impact of fatigue on motivation and mental functions remained unchanged, thus suggesting that fatigue might still influence the motivation to engage in PA after pulmonary rehabilitation.

The number of pack years also remained independently associated with low PA. Smoking per se might have a deleterious effect on muscle metabolism and 
may induce skeletal muscle dysfunction ${ }^{137}$. It is not clear whether these effects are direct or indirect, the latter as a result of life style and level of physical activity.

Symptom burden, including multiple dimensions of concurrent symptoms is suggested to result in a multiplicative experience for the individual. According to the theory of unpleasant symptoms this leads to an even greater impact on functional performance i.e. physical activity ${ }^{58}$. Even though the patients in our study with low PA had a significantly higher burden of physical symptoms, when using multiple logistic regression analysis, this was not an independent predictor of low PA.

Neither FM index nor FFM index were related to low PA in the present study. In disagreement with our findings, Monteira et al. ${ }^{102}$ found that inactive patients had significantly higher FM and that higher FM was negatively correlated with the level of PA. However, this correlation between FM and PA was weak. From our finding we cannot say that greater FM is a central reason for reporting low PA in patients with stable COPD.

\section{The relationship between experience of fatigue and physical capacity and disease severity in men and women}

In line with others 407077 our study showed that experience of fatigue is common in patients with stable COPD. Furthermore, the prevalence, experience (frequency, duration and severity) and the number of patients with no, moderate and severe fatigue was similar in men and women which is in agreement with previous studies ${ }^{76-77}$.

Men with fatigue had worse physical capacity (lung function, exercise capacity, and lower limb strength) and worse disease severity than men without fatigue. The findings among the men are in line with what others have found in mixed samples ${ }^{49} 78$ 81-82 86 . Reduced exercise capacity / aerobic capacity 
and pathophysiological changes within the muscle, including loss of muscle strength, endurance and muscle fatigue are among several proposed reasons for experiencing fatigue in chronic illness ${ }^{72} 138$. The lower exercise capacity and lower limb strength in men with fatigue found in our study is also supportive of this. Women with fatigue had comparable physical capacity and disease severity as women without fatigue, except for a significantly higher subjective leg fatigue after the exercise capacity test. Apart from the higher leg fatigue, the findings among the women suggest that experience of fatigue in women may be related to factors others than physical capacity or disease severity. Our results imply that the aetiology of fatigue in men and women with COPD might differ.

Other factors not directly related to the disease seem to influence the perception of both respiratory symptoms and health in women with COPD. The EUROSCOPE study ${ }^{106}$, which included 816 men and 312 women with COPD, showed that respiratory symptoms (wheeze, dyspnoea, cough and phlegm) were associated with lung function in men only. Another populationbased study found that women with or without COPD reported similar health status, whereas men with COPD reported significantly worse health status than men without COPD ${ }^{139}$. It was concluded that COPD seems to have a greater impact on perceived health status in men than in women. Other studies have shown fatigue to be predictive of self-reported health in patients with COPD ${ }^{80}$. Further exploration of the aetiology of fatigue would be useful to develop appropriate strategies to relieve this symptom in this group of patients.

The higher subjective leg fatigue in women in our study is interesting and suggests that there might be a link between peripheral muscle function and the presence of fatigue in women. It is well known that COPD is related to a muscle fibre type shift with a reduction in the proportion of type 1 fibres (slow-twitch oxidative, fatigue resistant ) and augmentation of the proportion of type 2 fibres (fast-twitch glycolytic, fatigue-prone). This could be an explanation to the increased muscle fatigability and reduced endurance in this group of patients ${ }^{137}$. In addition, muscle fatigue in COPD has been attributed 
to lower levels of high-energy phosphates, lower mitochondrial density, early lactacidemia and reduced muscle perfusion ${ }^{140}$. Skeletal muscle dysfunction is seen as a central contributor to the limitation in exercise capacity found in patients with COPD ${ }^{28}$ but there have been few comparisons of skeletal muscle dysfunction in men and women. One study showed no difference in fibre type composition, mitochondrial density or muscle enzyme activities in the quadriceps femoris among men and women with COPD and similar exercise capacity ${ }^{141}$. On the other hand, Janaudis-Ferreira et al. ${ }^{32}$ found more pronounced thigh muscle dysfunction, including muscle fatigue, among women than in men with COPD. The mechanisms behind the peripheral muscle dysfunction in COPD are complex ${ }^{142-143}$. It is still difficult to explain the higher perceived leg fatigue in women with fatigue without a significantly reduced exercise capacity or worse muscle strength compared to women without fatigue.

Even though no differences were found in physical capacity in women with and without fatigue when performing multiple regression analysis (II), exercise capacity was independently associated with the presence of fatigue in men as well as in women. This suggests that exercise training might influence the experience of fatigue in both men and women. Although pulmonary rehabilitation is known to increase exercise capacity and reduce symptoms of both dyspnoea and fatigue, supporting the functional status model defined by Leidy ${ }^{23}$, the relationship between gains in exercise capacity and reduction of symptoms is weak ${ }^{144-145}$. This weak relation could in part be explained by differences between men and women in how COPD impacts on physical capacity and symptoms. A recently systematic review evaluating the impact of sex on outcomes of pulmonary rehabilitation was inconclusive ${ }^{146}$ and could not rule out the possibility that sex-related differences might exist. It is possible that men and women need to focus on different therapies in their rehabilitation to reach an optimal effect. 


\section{Methodological issues and limitations}

The cross-sectional design of the studies in this thesis is limited in itself in that no causal relationships can be outlined. Another limitation is the sample selection, which excluded patients with pronounced co-morbidity in whom experience of fatigue might be greater and physically activity more affected. However, regarding co-morbidity, neither Waschki et al. ${ }^{53}$ nor Katajisto et al. 65 found any differences between patients with different levels of PA, suggesting that co-morbidity might be of minor importance in relation to PA. The patients included in our study had mainly moderate or severe airflowlimitation (GOLD 2 and GOLD 3) so generalization of the result to patients with grades 1 and 4 should be done cautiously.

\section{Physical activity}

In this thesis, PA was measured using the IPAQ. However, PA as measured with a questionnaire has lower validity than assessing PA with objective measurements ${ }^{147}$. Therefore, we also assessed PA with an accelerometer in a smaller number of patients to assure convergent validity. The correlation coefficient between the IPAQ-S total MET min/week and the average dayactivity counts was above 0.5 , which has been considered as adequate construct validity by van Poppel at al. ${ }^{148}$ and was in line with that found by Tomioka et al. ${ }^{149}$ in elderly men and women.

\section{Fatigue}

Fatigue was assessed as a symptom and conceptualized as a multidimensional experience including timing (frequency and duration) and severity (or intensity) ${ }^{150}$. This assessment of the experience of fatigue considers the symptom itself rather than the impact of fatigue on different functions ${ }^{150}$. One previous study on fatigue in patients with COPD found a relationship between fatigue severity and self-reported physical, psycho-social and 
cognitive limitations due to fatigue ${ }^{75}$. However, this study only considered the severity dimension of fatigue. As fatigue is a symptom with several dimensions ${ }^{58}$ we also included frequency and duration to distinguish sufferers with a nearly constant experience of severe fatigue. One hypothesis was that the extent to which severe fatigue is experienced is important, and that the more constant the experience of severe fatigue, the greater the impact on PA. Our finding of an association between severe fatigue and low PA gives support to the theory of unpleasant symptoms ${ }^{58}$.

\section{Clinical implications and future research}

In the 2013 updated GOLD-COPD document ${ }^{8}$ symptoms have been given a more central place in the assessment of the disease as well as in the evaluation of treatment effects. The main symptom dyspnoea is often assigned a central role in the vicious decline in physical function in patients with COPD ${ }^{56}$. This thesis shows that the experience of fatigue seems to be an important symptom related to worse physical function. Our results also show that severe fatigue is significantly associated with low PA, and needs attention. Severe fatigue might have a devastating effect on the patient's ability to adhere to the recommended level of physical activity to maintain health. According to guidelines ${ }^{18}$, promoting physical activity is important in all patients with COPD, but patients with severe fatigue might need specific strategies to become more physically active. Combining exercise training programs to increase physical capacity with exercise counselling programs might be a successful strategy and has also been suggested by a recent review on how to enhance PA in COPD ${ }^{56}$.

In a qualitative study by Stridsman et al. ${ }^{151}$ it was found that patients with COPD do not mention their experience of fatigue to health-care professionals. This underlines the importance of actively asking about fatigue. Assessing the experience of fatigue by asking structured questions regarding the frequency, duration and severity may provide important information to detect patients 
with severe fatigue who are at risk of being physically inactive. The use of such questions in a clinical setting might be valuable.

Our result of an association between exercise capacity and experience of fatigue in both men and women supports the theory that endurance exercise training might influence the experience of fatigue in both sexes. Recent studies have shown that patients with pronounced exercise-induced muscle fatigue ${ }^{152-}$ 153154 show favourable effects of training on both exercise capacity and different dimensions of HRQL. Muscle endurance training might be extra important in the rehabilitation of women with COPD experiencing fatigue However, our findings among the women warrant further investigation using more sophisticated methods to assess muscle strength, muscle endurance and muscle fatigue to confirm the association between leg fatigue, i.e. muscle fatigue, and experience of fatigue in women. 


\section{CONCLUSIONS}

- Forty two percent of the patients had low physical activity.

- A majority experienced fatigue, with no difference between men and women.

- Severe fatigue, worse exercise capacity and a higher amount of smoking were independently associated with low physical activity.

- Men with fatigue had worse physical capacity and disease severity compared to men without fatigue. Women with fatigue had similar physical capacity and disease severity compared to women without fatigue except for higher perceived leg fatigue immediately after an exercise capacity test.

- Multiple regression analysis showed that exercise capacity and disease severity were associated with the presence of fatigue in both men and women. In addition, in women leg fatigue was strongly associated with the presence of fatigue. 


\section{POPULÄRVETENSKAPLIG SAMMANFATTNING (SUMMARY IN SWEDISH)}

Kroniskt Obstruktiv Lungsjukdom (KOL) är en folksjukdom som ökar i hela världen. Sjukdomen ökar bland kvinnor och verkar plana ut bland män. Den mest kända orsaken till KOL är rökning. KOL betraktas numera som en sjukdom med effekter inte bara i lungan utan även i andra organsystem. Viktminskning och minskad muskelmassa är exempel på sådana s.k. systemiska effekter som kan bidra till den försämrade fysiska funktionen som är vanlig vid KOL. Patienter med KOL rapporterar också ett brett register av symtom. De vanligaste är andfåddhet och trötthet. Sambandet mellan fysisk funktion och symptom vid KOL är bristfälligt klarlagt, framförallt bland kvinnor med KOL.

Huvudsyftet med denna avhandling var att undersöka sambandet mellan två dimensioner av fysisk funktion (fysisk aktivitet och fysisk kapacitet) och upplevelsen av trötthet hos patienter med KOL i ett stabilt skede. I delarbete I var syftet att beskriva den fysiska aktivitetsnivån samt att undersöka vilka faktorer som var associerade med låg fysisk aktivitet. I delarbete II var syftet att undersöka upplevelsen av trötthet hos män och kvinnor och relationen mellan förekomsten av trötthet och fysisk kapacitet och sjukdomens svårighetsgrad hos män respektive hos kvinnor.

I en tvärsnittsstudie undersöktes 121 patienter (67 kvinnor) med KOL med en medelålder på 67 år. Undersökningen omfattade uppskattning av fysisk aktivitet med hjälp av ett frågeformulär, mätning av fysisk kapacitet med avseende på lungfunktion (spirometri), fysisk kondition (sex minuters gångtest, andfåddhet och bentrötthet vid avslutat test) och muskelstyrka (benstyrka och greppstyrka). Kroppssammansättningen undersöktes med bioimpedans analys och muskelmassa och fettmassa beräknades. Patienterna fick rapportera hur ofta, hur länge och hur svår trötthet de upplevt den 
senaste månaden. De som svarade att de inte upplevt någon trötthet kategoriserades som "inte trötta". De som upplevt svår trötthet i 15 dagar eller mer med en varaktighet på mer än sex timmar var gång kategoriserades som "svårt trötta". Alla andra kategoriserades som "måttligt trötta". Patienterna fick också rapportera andra symptom som grad av andfåddhet i vardagliga aktiviteter, oro och nedstämdhet. Patienterna lämnade också uppgifter om rökning.

Resultatet visade att $42 \%$ av patienterna hade låg fysisk aktivitetsnivå. Majoriteten hade upplevt trötthet den senaste månaden, 52 \% måttlig trötthet och $22 \%$ svår trötthet. Låg fysisk aktivitet var associerat med sämre fysisk kondition, en högre tobakskonsumtion och upplevelse av svår trötthet.

Män som upplevde trötthet hade sämre lungfunktion, sämre kondition och muskelstyrka och svårare sjukdom jämfört med män som inte var trötta. Kvinnor som rapporterade trötthet jämfört med kvinnor utan någon upplevelse av trötthet hade likvärdig lungfunktion, fysisk kondition, muskelstyrka och svårighetsgrad av sjukdomen men de upplevde en högre bentrötthet i samband med gångtestet än de som inte var trötta. I en analys där sambandet mellan trötthet och flera mått på fysisk kapacitet undersöktes samtidigt visade dock att den fysiska konditionen och sjukdomens svårighetsgrad var associerat med trötthet hos både män och kvinnor men hos kvinnorna var bentrötthet en stark faktor.

Resultatet indikerar att patienter som upplever svår trötthet kan behöva särskilt stöd för att öka sin fysiska aktivitet. Träning av muskeluthålligheten skulle kunna vara extra värdefullt framför allt i rehabiliteringen av kvinnor med KOL som upplever trötthet. Sambandet mellan trötthet och ansträngningsutlöst bentrötthet bland kvinnorna behöver dock studeras ytterligare. 


\section{ACKNOWLEDGEMENTS}

I want to express my gratitude and thankfulness to all of you who helped me to complete this thesis. In particular I would like to thank:

Linköping University, for giving me the possibility to undergo education in research and research training.

The Department of Pulmonary medicine, Linköping Universtiy Hospital and Helena Engström the head of the department for giving me the time to complete this project.

All patients that willingly took part in this study.

Mitra Unosson, professor emeritus, my main supervisor for your great knowledge and patience while guiding me through this process. Your endless enthusiasm for research is inspiring and I appreciate our fruitful research discussions, for giving encouragement when needed and for your hospitality.

Elisabeth Skargren, associate professor, my co-supervisor. Thank you for always taking the time even when there was no time and for excellent guidance on the way.

Per Jakobsson, my other co-supervisor. Thank you for your support and constructive advice and for sharing your knowledge in respiratory medicine.

Kersti Theander, co-author. Your research work was the foundation for this project. Thank you for being so positive and for giving thoughtful viewpoints during the work process.

Magnus Kentson, co-author for valuable thoughts and input in this project and for taking part in the recruitment of patients in Jönköping.

Elizabeth Häggquist, my college in Jönköping who with great accuracy assessed the patients included in Jönköping. 
Professor Tiny Jaarsma and all the PhD students at the division of Health, Activity, Care, Department of Social and Welfare Studies Linköping University for taking part in my research, reading manuscripts and encouraging me in hard times and giving me a good time. The best division ever!

All my colleges and friends at the Pulmonary Department at the University Hospital in Linköping and in particular Izabella Sandberg, Maria Petersson for obtaining the blood samples and Helen Anzén and Disa Jonsdottir my closest colleges for being nice and supportive the whole time.

My colleges at the Division of Physiotherapy for being inclusive and taking interest in my work.

Annika, Anette, Elisabeth and Helen my friends for cheering me up and Catharina, Marianne and Johanna my friends in Ryttargårdskyrkan for best support when needed.

Ulla Walfridsson my friend for being you. You are the nicest and most caring friend one can have.

Christa Tödt-Braesen my mother-in-law for always caring and encouraging my research work.

Marianne and Sigvard Bengtsson, my parents for your love and care and your positive view on life.

Sara, Mattias and Johannes. You are the most important in my life. You give me such great joy.

Tim, my husband for loving me despite knowing me and for the great support to finalise this thesis.

This work has been supported by grants from the Swedish Heart-Lung Foundation, the Swedish Heart and Lung Association, the County Council of Östergötland and the Medical Research Council of Southeast Sweden (FORSS). 


\section{REFERENCES}

1. Chapman KR, Mannino DM, Soriano JB, Vermeire PA, Buist AS, Thun MJ, et al. Epidemiology and costs of chronic obstructive pulmonary disease. Eur Respir J 2006;27(1):188-207.

2. Celli BR. Chronic obstructive pulmonary disease: from unjustified nihilism to evidence-based optimism. Proc Am Thorac Soc 2006;3(1):58-65.

3. Lindberg A, Bjerg A, Ronmark E, Larsson LG, Lundback B. Prevalence and underdiagnosis of COPD by disease severity and the attributable fraction of smoking Report from the Obstructive Lung Disease in Northern Sweden Studies. Respir Med 2006;100(2):264-72.

4. Lindberg A, Jonsson AC, Ronmark E, Lundgren R, Larsson LG, Lundback B. Prevalence of chronic obstructive pulmonary disease according to BTS, ERS, GOLD and ATS criteria in relation to doctor's diagnosis, symptoms, age, gender, and smoking habits. Respiration 2005;72(5):4719.

5. Mannino DM, Homa DM, Akinbami LJ, Ford ES, Redd SC. Chronic obstructive pulmonary disease surveillance--United States, 1971-2000. Respir Care 2002;47(10):1184-99.

6. Lofdahl K, Strom K. Increasing morbidity and mortality in women with COPD. Läkartidningen 2007;104(13):1040-2.

7. Vestbo J, Hurd SS, Agusti AG, Jones PW, Vogelmeier C, Anzueto A, et al. Global strategy for the diagnosis, management, and prevention of chronic obstructive pulmonary disease: GOLD executive summary. Am J Respir Crit Care Med 2013;187(4):347-65.

8. Global Stragei for the diagnosis, management and prevention of chronic obstrucitve pulmonary disease GOLD. 2013. [Cited 2013 Dec 20]; Available from: www.goldcopd.org/.

9. Celli BR, MacNee W. Standards for the diagnosis and treatment of patients with COPD: a summary of the ATS/ERS position paper. Eur Respir J 2004;23(6):932-46.

10. Rabe KF, Hurd S, Anzueto A, Barnes PJ, Buist SA, Calverley P, et al. Global strategy for the diagnosis, management, and prevention of chronic obstructive pulmonary disease: GOLD executive summary. Am J Respir Crit Care Med 2007;176(6):532-55. 
11. Camp PG, Coxson HO, Levy RD, Pillai SG, Anderson W, Vestbo J, et al. Sex differences in emphysema and airway disease in smokers. Chest 2009;136(6):1480-8.

12. Dransfield MT, Washko GR, Foreman MG, Estepar RS, Reilly J, Bailey WC. Gender differences in the severity of CT emphysema in COPD. Chest 2007;132(2):464-70.

13. Martinez FJ, Curtis JL, Sciurba F, Mumford J, Giardino ND, Weinmann G, et al. Sex differences in severe pulmonary emphysema. Am J Respir Crit Care Med 2007;176(3):243-52.

14. Watson L, Vonk JM, Lofdahl CG, Pride NB, Pauwels RA, Laitinen LA, et al. Predictors of lung function and its decline in mild to moderate COPD in association with gender: results from the Euroscop study. Respir Med 2006;100(4):746-53.

15. Nationellt vårdprogram för KOL, kroniskt obstruktiv lungsjukdom: Svensk Lungmedicinsk förening. [Cited 2014 Febr 22]; Available from: http://slmf.se/kol/

16. Barnes PJ, Celli BR. Systemic manifestations and comorbidities of COPD. Eur Respir J 2009;33(5):1165-85.

17. Nussbaumer-Ochsner Y, Rabe KF. Systemic manifestations of COPD. Chest 2011;139(1):165-73.

18. Spruit MA, Singh SJ, Garvey C, ZuWallack R, Nici L, Rochester C, et al. An official American Thoracic Society/European Respiratory Society statement: key concepts and advances in pulmonary rehabilitation. Am J Respir Crit Care Med 2013;188(8):e13-64.

19. Gloeckl R, Marinov B, Pitta F. Practical recommendations for exercise training in patients with COPD. Eur Respir Rev 2013;22(128):178-86.

20. Kapella MC, Larson JL, Covey MK, Alex CG. Functional performance in chronic obstructive pulmonary disease declines with time. Med Sci Sports Exerc 2011;43(2):218-24.

21. MacIntyre NR. Mechanisms of functional loss in patients with chronic lung disease. Respir Care 2008;53(9):1177-84.

22. Eisner MD, Blanc PD, Yelin EH, Sidney S, Katz PP, Ackerson L, et al. COPD as a systemic disease: impact on physical functional limitations. Am J Med 2008;121(9):789-96.

23. Leidy NK. Functional status and the forward progress of merry-go-rounds: toward a coherent analytical framework. Nurs Res 1994;43(4):196-202.

24. Leidy NK. Using functional status to assess treatment outcomes. Chest 1994;106(6):1645-6. 
25. Jeng C, Chang W, Wai PM, Chou CL. Comparison of oxygen consumption in performing daily activities between patients with chronic obstructive pulmonary disease and a healthy population. Heart Lung 2003;32(2):12130.

26. Rochester CL. Exercise training in chronic obstructive pulmonary disease. J Rehabil Res Dev 2003;40(5 Suppl 2):59-80.

27. O'Donnell DE. Ventilatory limitations in chronic obstructive pulmonary disease. Med Sci Sports Exerc 2001;33(7 Suppl):S647-55.

28. Debigare R, Maltais F. Last Word on Point:Counterpoint: The major limitation to exercise performance in COPD is 1) inadequate energy supply to the respiratory and locomotor muscles, 2) lower limb muscle dysfunction, 3) dynamic hyperinflation. J Appl Physiol 2008;105(2):764.

29. Allaire J, Maltais F, Doyon JF, Noel M, LeBlanc P, Carrier G, et al.

Peripheral muscle endurance and the oxidative profile of the quadriceps in patients with COPD. Thorax 2004;59(8):673-8.

30. Coronell C, Orozco-Levi M, Mendez R, Ramirez-Sarmiento A, Galdiz JB, Gea J. Relevance of assessing quadriceps endurance in patients with COPD. Eur Respir J 2004;24(1):129-36.

31. Saey D, Michaud A, Couillard A, Cote CH, Mador MJ, LeBlanc P, et al. Contractile fatigue, muscle morphometry, and blood lactate in chronic obstructive pulmonary disease. Am J Respir Crit Care Med 2005;171(10):1109-15.

32. Janaudis-Ferreira T, Wadell K, Sundelin G, Lindstrom B. Thigh muscle strength and endurance in patients with COPD compared with healthy controls. Respir Med 2006;100(8):1451-7.

33. de Torres JP, Casanova C, Hernandez C, Abreu J, Montejo de Garcini A, Aguirre-Jaime A, et al. Gender associated differences in determinants of quality of life in patients with COPD: a case series study. Health Qual Life Outcomes 2006;4:72.

34. Laviolette L, Lacasse Y, Doucet M, Lacasse M, Marquis K, Saey D, et al. Chronic obstructive pulmonary disease in women. Can Respir J 2007;14(2):93-8.

35. WHO. Physical activity. 2014. [Cited 2014 Feb 20]; Available from: http://www.who.int/mediacentre/factsheets/fs385/en/.

36. Nelson ME, Rejeski WJ, Blair SN, Duncan PW, Judge JO, King AC, et al. Physical activity and public health in older adults: recommendation from the American College of Sports Medicine and the American Heart Association. Circulation 2007;116(9):1094-105. 
37. Jette M, Sidney K, Blumchen G. Metabolic equivalents (METS) in exercise testing, exercise prescription, and evaluation of functional capacity. Clin Cardiol 1990;13(8):555-65.

38. Ainsworth BE, Haskell WL, Herrmann SD, Meckes N, Bassett DR, Jr., Tudor-Locke C, et al. 2011 Compendium of Physical Activities: a second update of codes and MET values. Med Sci Sports Exerc 2011;43(8):157581.

39. Vorrink SN, Kort HS, Troosters T, Lammers JW. Level of daily physical activity in individuals with COPD compared with healthy controls. Respir Res 2011;12:33.

40. Arne M, Janson C, Janson S, Boman G, Lindqvist U, Berne C, et al. Physical activity and quality of life in subjects with chronic disease: chronic obstructive pulmonary disease compared with rheumatoid arthritis and diabetes mellitus. Scand J Prim Health Care 2009;27(3):141-7.

41. Pitta F, Troosters T, Spruit MA, Probst VS, Decramer M, Gosselink R. Characteristics of physical activities in daily life in chronic obstructive pulmonary disease. Am J Respir Crit Care Med 2005;171(9):972-7.

42. Troosters T, Sciurba F, Battaglia S, Langer D, Valluri SR, Martino L, et al. Physical inactivity in patients with COPD, a controlled multi-center pilot-study. Respir Med 2010;104(7):1005-11.

43. Watz H, Waschki B, Meyer T, Magnussen H. Physical activity in patients with COPD. Eur Respir J 2009;33(2):262-72.

44. Garcia-Aymerich J, Lange P, Benet M, Schnohr P, Anto JM. Regular physical activity reduces hospital admission and mortality in chronic obstructive pulmonary disease: a population based cohort study. Thorax 2006;61(9):772-8.

45. Pitta F, Troosters T, Probst VS, Spruit MA, Decramer M, Gosselink R. Physical activity and hospitalization for exacerbation of COPD. Chest 2006;129(3):536-44.

46. Waschki B, Kirsten A, Holz O, Muller KC, Meyer T, Watz H, et al. Physical activity is the strongest predictor of all-cause mortality in patients with COPD: a prospective cohort study. Chest 2011;140(2):331-42.

47. Benzo RP, Chang CC, Farrell MH, Kaplan R, Ries A, Martinez FJ, et al. Physical activity, health status and risk of hospitalization in patients with severe chronic obstructive pulmonary disease. Respiration 2010;80(1):10-8.

48. Esteban C, Quintana JM, Aburto M, Moraza J, Egurrola M, Perez-Izquierdo $\mathrm{J}$, et al. Impact of changes in physical activity on health-related quality of life among patients with COPD. Eur Respir J 2010;36(2):292-300. 
49. Belza B, Steele BG, Hunziker J, Lakshminaryan S, Holt L, Buchner DM.

Correlates of physical activity in chronic obstructive pulmonary disease. Nurs Res 2001;50(4):195-202.

50. Garcia-Aymerich J, Serra I, Gomez FP, Farrero E, Balcells E, Rodriguez DA, et al. Physical activity and clinical and functional status in COPD. Chest 2009;136(1):62-70.

51. Pitta F, Troosters T, Probst VS, Lucas S, Decramer M, Gosselink R. Potential consequences for stable chronic obstructive pulmonary disease patients who do not get the recommended minimum daily amount of physical activity. J Bras Pneumol 2006;32(4):301-8.

52. Andersson M, Slinde F, Gronberg AM, Svantesson U, Janson C, Emtner M. Physical activity level and its clinical correlates in chronic obstructive pulmonary disease: a cross-sectional study. Respir Res 2013;14:128.

53. Waschki B, Spruit MA, Watz H, Albert PS, Shrikrishna D, Groenen M, et al. Physical activity monitoring in COPD: compliance and associations with clinical characteristics in a multicenter study. Respir Med 2012;106(4):52230 .

54. Hirayama F, Lee AH, Binns CW, Leong CC, Hiramatsu T. Physical activity of patients with chronic obstructive pulmonary disease: implications for pulmonary rehabilitation. J Cardiopulm Rehabil Prev 2008;28(5):330-4.

55. Watz H, Waschki B, Boehme C, Claussen M, Meyer T, Magnussen H. Extrapulmonary effects of chronic obstructive pulmonary disease on physical activity: a cross-sectional study. Am J Respir Crit Care Med 2008;177(7):743-51.

56. Troosters T, van der Molen T, Polkey M, Rabinovich RA, Vogiatzis I, Weisman I, et al. Improving physical activity in COPD: towards a new paradigm. Respir Res 2013;14:115.

57. Dodd M, Janson S, Facione N, Faucett J, Froelicher ES, Humphreys J, et al. Advancing the science of symptom management. J Adv Nurs 2001;33(5):668-76.

58. Lenz ER, Pugh LC, Milligan RA, Gift A, Suppe F. The middle-range theory of unpleasant symptoms: an update. ANS Adv Nurs Sci 1997;19(3):14-27.

59. Zambroski CH, Moser DK, Bhat G, Ziegler C. Impact of symptom prevalence and symptom burden on quality of life in patients with heart failure. Eur J Cardiovasc Nurs 2005;4(3):198-206.

60. Guyatt GH, Berman LB, Townsend M, Pugsley SO, Chambers LW. A measure of quality of life for clinical trials in chronic lung disease. Thorax 1987;42(10):773-8. 
61. Corhay JL, Dang DN, Van Cauwenberge H, Louis R. Pulmonary rehabilitation and COPD: providing patients a good environment for optimizing therapy. Int J Chron Obstruct Pulmon Dis 2014;9:27-39.

62. Dyspnea. Mechanisms, assessment, and management: a consensus statement. American Thoracic Society. Am J Respir Crit Care Med 1999;159(1):321-40.

63. Parshall MB, Schwartzstein RM, Adams L, Banzett RB, Manning HL, Bourbeau J, et al. An official American Thoracic Society statement: update on the mechanisms, assessment, and management of dyspnea. Am J Respir Crit Care Med 2012;185(4):435-52.

64. Baghai-Ravary R, Quint JK, Goldring JJ, Hurst JR, Donaldson GC, Wedzicha JA. Determinants and impact of fatigue in patients with chronic obstructive pulmonary disease. Respir Med 2009;103(2):216-23.

65. Katajisto M, Kupiainen H, Rantanen P, Lindqvist A, Kilpelainen M, Tikkanen $\mathrm{H}$, et al. Physical inactivity in COPD and increased patient perception of dyspnea. Int J Chron Obstruct Pulmon Dis 2012;7:743-55.

66. de Torres JP, Casanova C, Montejo de Garcini A, Aguirre-Jaime A, Celli BR. Gender and respiratory factors associated with dyspnea in chronic obstructive pulmonary disease. Respir Res 2007;8:18.

67. Franssen PM, Bultmann U, Kant I, van Amelsvoort LG. The association between chronic diseases and fatigue in the working population. $J$ Psychosom Res 2003;54(4):339-44.

68. Kapella MC, Larson JL, Patel MK, Covey MK, Berry JK. Subjective fatigue, influencing variables, and consequences in chronic obstructive pulmonary disease. Nurs Res 2006;55(1):10-7.

69. Kinsman RA, Yaroush RA, Fernandez E, Dirks JF, Schocket M, Fukuhara J. Symptoms and experiences in chronic bronchitis and emphysema. Chest 1983;83(5):755-61.

70. Theander K, Unosson M. Fatigue in patients with chronic obstructive pulmonary disease. J Adv Nurs 2004;45(2):172-7.

71. Blinderman CD, Homel P, Billings JA, Tennstedt S, Portenoy RK. Symptom distress and quality of life in patients with advanced chronic obstructive pulmonary disease. J Pain Symptom Manage 2009;38(1):115-23.

72. Piper F. Fatigue. In: Carrieri-Kohlman V, Lindsey AM, West CM, editors. Pathophysiological phenomena in nursing. 3rd ed. St. Louis: Saunders, 2003:209-34.

73. Ream E, Richardson A. Fatigue: a concept analysis. Int J Nurs Stud 1996;33(5):519-29. 
74. Ream E, Richardson A. Fatigue in patients with cancer and chronic obstructive airways disease: a phenomenological enquiry. Int J Nurs Stud 1997;34(1):44-53.

75. Theander K, Jakobsson P, Torstensson O, Unosson M. Severity of fatigue is related to functional limitation and health in patients with chronic obstructive pulmonary disease. Int J Nurs Pract 2008;14(6):455-62.

76. Lewko A, Bidgood PL, Garrod R. Evaluation of psychological and physiological predictors of fatigue in patients with COPD. BMC Pulm Med 2009;9:47.

77. Theander K, Unosson M. No gender differences in fatigue and functional limitations due to fatigue among patients with COPD. J Clin Nurs 2011;20(9-10):1303-10.

78. Al-shair K, Kolsum U, Berry P, Smith J, Caress A, Singh D, et al. Development, dimensions, reliability and validity of the novel Manchester COPD fatigue scale. Thorax 2009;64(11):950-5.

79. Small S, Lamb M. Fatigue in chronic illness: the experience of individuals with chronic obstructive pulmonary disease and with asthma. J Adv Nurs 1999;30(2):469-78.

80. Nguyen HQ, Donesky-Cuenco D, Carrieri-Kohlman V. Associations between symptoms, functioning, and perceptions of mastery with global self-rated health in patients with COPD: a cross-sectional study. Int J Nurs Stud 2008;45(9):1355-65.

81. Breslin E, van der Schans C, Breukink S, Meek P, Mercer K, Volz W, et al. Perception of fatigue and quality of life in patients with COPD. Chest 1998;114(4):958-64.

82. Breukink SO, Strijbos JH, Koorn M, Koeter GH, Breslin EH, van der Schans $\mathrm{CP}$. Relationship between subjective fatigue and physiological variables in patients with chronic obstructive pulmonary disease. Respir Med 1998;92(4):676-82.

83. Paddison JS, Effing TW, Quinn S, Frith PA. Fatigue in COPD: association with Functional Status and Hospitalisations. Eur Respir J 2013;41(3):56570.

84. Ryan JL, Carroll JK, Ryan EP, Mustian KM, Fiscella K, Morrow GR. Mechanisms of cancer-related fatigue. Oncologist 2007;12 Suppl 1:22-34.

85. Evans WJ, Lambert CP. Physiological basis of fatigue. Am J Phys Med Rehabil 2007;86(1 Suppl):S29-46.

86. Yeh ML, Chen HH, Liao YC, Liao WY. Testing the functional status model in patients with chronic obstructive pulmonary disease. J Adv Nurs 2004;48(4):342-50. 
87. Oh EG, Kim CJ, Lee WH, Kim SS. Correlates of fatigue in Koreans with chronic lung disease. Heart Lung 2004;33(1):13-20.

88. Whitehead L. The measurement of fatigue in chronic illness: a systematic review of unidimensional and multidimensional fatigue measures. $J$ Pain Symptom Manage 2009;37(1):107-28.

89. Lai JS, Cella D, Choi S, Junghaenel DU, Christodoulou C, Gershon R, et al. How item banks and their application can influence measurement practice in rehabilitation medicine: a PROMIS fatigue item bank example. Arch Phys Med Rehabil 2011;92(10 Suppl):S20-7.

90. Al-shair K, Dockry R, Mallia-Milanes B, Kolsum U, Singh D, Vestbo J. Depression and its relationship with poor exercise capacity, BODE index and muscle wasting in COPD. Respir Med 2009;103(10):1572-9.

91. Heerema-Poelman A, Stuive I, Wempe JB. Adherence to a maintenance exercise program 1 year after pulmonary rehabilitation: what are the predictors of dropout? J Cardiopulm Rehabil Prev 2013;33(6):419-26.

92. Camp PG, Goring SM. Gender and the diagnosis, management, and surveillance of chronic obstructive pulmonary disease. Proc Am Thorac Soc 2007;4(8):686-91.

93. Naberan K, Azpeitia A, Cantoni J, Miravitlles M. Impairment of quality of life in women with chronic obstructive pulmonary disease. Respir Med 2012;106(3):367-73.

94. Jablonski A, Gift A, Cook KE. Symptom assessment of patients with chronic obstructive pulmonary disease. West J Nurs Res 2007;29(7):84563.

95. Bausewein C, Booth S, Gysels M, Kuhnbach R, Haberland B, Higginson IJ. Understanding breathlessness: cross-sectional comparison of symptom burden and palliative care needs in chronic obstructive pulmonary disease and cancer. J Palliat Med 2010;13(9):1109-18.

96. Celli BR, Cote CG, Marin JM, Casanova C, Montes de Oca M, Mendez RA, et al. The body-mass index, airflow obstruction, dyspnea, and exercise capacity index in chronic obstructive pulmonary disease. $N$ Engl J Med 2004;350(10):1005-12.

97. Celli BR. Predictors of mortality in COPD. Respir Med 2010;104(6):773-9.

98. de Torres JP, Cote CG, Lopez MV, Casanova C, Diaz O, Marin JM, et al. Sex differences in mortality in patients with COPD. Eur Respir J 2009;33(3):528-35.

99. de Torres JP, Casanova C, de Garcini AM, Jaime AA, Celli BR. COPD heterogeneity: gender differences in the multidimensional BODE index. Int J Chron Obstruct Pulmon Dis 2007;2(2):151-5. 
100. Wust RC, Degens H. Factors contributing to muscle wasting and dysfunction in COPD patients. Int J Chron Obstruct Pulmon Dis 2007;2(3):289-300.

101. Eisner MD, Blanc PD, Sidney S, Yelin EH, Lathon PV, Katz PP, et al. Body composition and functional limitation in COPD. Respir Res 2007;8:7.

102. Monteiro F, Camillo CA, Vitorasso R, Sant'Anna T, Hernandes NA, Probst VS, et al. Obesity and physical activity in the daily life of patients with COPD. Lung 2012;190(4):403-10.

103. Alonso J, Ferrer M, Gandek B, Ware JE, Jr., Aaronson NK, Mosconi P, et al. Health-related quality of life associated with chronic conditions in eight countries: results from the International Quality of Life Assessment (IQOLA) Project. Qual Life Res 2004;13(2):283-98.

104. Hartman JE, Boezen HM, de Greef MH, Bossenbroek L, ten Hacken NH. Consequences of physical inactivity in chronic obstructive pulmonary disease. Expert Rev Respir Med 2010;4(6):735-45.

105. Han MK, Postma D, Mannino DM, Giardino ND, Buist S, Curtis JL, et al. Gender and chronic obstructive pulmonary disease: why it matters. Am J Respir Crit Care Med 2007;176(12):1179-84.

106. Watson L, Schouten JP, Lofdahl CG, Pride NB, Laitinen LA, Postma DS. Predictors of COPD symptoms: does the sex of the patient matter? Eur Respir J 2006;28(2):311-8.

107. Brusasco V, Crapo R, Viegi G. Coming together: the ATS/ERS consensus on clinical pulmonary function testing. Eur Respir J 2005;26(1):1-2.

108. ATS statement: guidelines for the six-minute walk test. Am J Respir Crit Care Med 2002;166(1):111-7.

109. Borg GA. Psychophysical bases of perceived exertion. Med Sci Sports Exerc 1982;14(5):377-81.

110. Nordenskiold UM, Grimby G. Grip force in patients with rheumatoid arthritis and fibromyalgia and in healthy subjects. A study with the Grippit instrument. Scand J Rheumatol 1993;22(1):14-9.

111. Csuka M, McCarty DJ. Simple method for measurement of lower extremity muscle strength. Am J Med 1985;78(1):77-81.

112. Craig CL, Marshall AL, Sjostrom M, Bauman AE, Booth ML, Ainsworth $\mathrm{BE}$, et al. International physical activity questionnaire: 12-country reliability and validity. Med Sci Sports Exerc 2003;35(8):1381-95.

113. Bestall JC, Paul EA, Garrod R, Garnham R, Jones PW, Wedzicha JA. Usefulness of the Medical Research Council (MRC) dyspnoea scale as a measure of disability in patients with chronic obstructive pulmonary disease. Thorax 1999;54(7):581-6. 
114. Lisspers J, Nygren A, Soderman E. Hospital Anxiety and Depression Scale (HAD): some psychometric data for a Swedish sample. Acta Psychiatr Scand 1997;96(4):281-6.

115. Portenoy RK, Thaler HT, Kornblith AB, Lepore JM, Friedlander-Klar H, Kiyasu E, et al. The Memorial Symptom Assessment Scale: an instrument for the evaluation of symptom prevalence, characteristics and distress. Eur J Cancer 1994;30A(9):1326-36.

116. Kyle UG, Bosaeus I, De Lorenzo AD, Deurenberg P, Elia M, Gomez JM, et al. Bioelectrical impedance analysis--part I: review of principles and methods. Clin Nutr 2004;23(5):1226-43.

117. WHO. Brief Health Information. 2003. [Cited 2006]; Available from: www.who.int/classifications/icf/training/icfchecklist.pdf.

118. Ekelund U, Sepp H, Brage S, Becker W, Jakes R, Hennings M, et al.

Criterion-related validity of the last 7-day, short form of the International Physical Activity Questionnaire in Swedish adults. Public Health Nutr 2006;9(2):258-65.

119.The IPAQ group. International Physical Activity Questionnaire Guidelines for data processing and analysis of the International Physical Activity Questionnaire (IPAQ) - short and long forms.[Cited 2009]; Available from: https://sites.google.com/site/theipaq/.

120. Hedenstrom H, Malmberg P, Agarwal K. Reference values for lung function tests in females. Regression equations with smoking variables. Bull Eur Physiopathol Respir 1985;21(6):551-7.

121. Hedenstrom H, Malmberg P, Fridriksson HV. Reference values for lung function tests in men: regression equations with smoking variables. Ups J Med Sci 1986;91(3):299-310.

122. Troosters T, Gosselink R, Decramer M. Six minute walking distance in healthy elderly subjects. Eur Respir J 1999;14(2):270-4.

123. Csuka M MD. Simple measurement for lower extremity muscle strenght. The American Journal of Medicine 1985;78:77-81.

124. Theander K, Cliffordson C, Torstensson O, Jakobsson P, Unosson M.

Fatigue Impact Scale: Its validation in patients with chronic obstructive pulmonary disease. Psychol Health Med 2007;12(4):470-84.

125. Nici L, Donner C, Wouters E, Zuwallack R, Ambrosino N, Bourbeau J, et al. American Thoracic Society/European Respiratory Society statement on pulmonary rehabilitation. Am J Respir Crit Care Med 2006;173(12):1390-413.

126. Kyle UG, Pichard C, Rochat T, Slosman DO, Fitting JW, Thiebaud D. New bioelectrical impedance formula for patients with respiratory 
insufficiency: comparison to dual-energy X-ray absorptiometry. Eur Respir J 1998;12(4):960-6.

127. Schols AM, Wouters EF, Soeters PB, Westerterp KR. Body composition by bioelectrical-impedance analysis compared with deuterium dilution and skinfold anthropometry in patients with chronic obstructive pulmonary disease. Am J Clin Nutr 1991;53(2):421-4.

128. VanItallie TB, Yang MU, Heymsfield SB, Funk RC, Boileau RA. Heightnormalized indices of the body's fat-free mass and fat mass: potentially useful indicators of nutritional status. Am J Clin Nutr 1990;52(6):953-9.

129. Field A. Discovering Statistics using SPSS. Third edition ed. Los Angeles, London, New Dehli, Singapore, Washington DC: SAGE Publications Ltd, 2009.

130. Depew ZS, Garofoli AC, Novotny PJ, Benzo RP. Screening for severe physical inactivity in chronic obstructive pulmonary disease: The value of simple measures and the validation of two physical activity questionnaires. Chron Respir Dis 2013;10(1):19-27.

131. Andersson M, Slinde F, Gronberg AM, Svantesson U, Janson C, Emtner M. Physical activity level and its clinical correlates in chronic obstructive pulmonary disease: a cross-sectional study. Respir Res 2013;14(1):128.

132. Arne M, Lundin F, Boman G, Janson C, Janson S, Emtner M. Factors associated with good self-rated health and quality of life in subjects with self-reported COPD. Int J Chron Obstruct Pulmon Dis 2011;6:511-9.

133. Garcia-Aymerich J, Felez MA, Escarrabill J, Marrades RM, Morera J, Elosua R, et al. Physical activity and its determinants in severe chronic obstructive pulmonary disease. Med Sci Sports Exerc 2004;36(10):1667-73.

134. Lacasse Y, Goldstein R, Lasserson TJ, Martin S. Pulmonary rehabilitation for chronic obstructive pulmonary disease. Cochrane Database Syst Rev 2006(4):CD003793.

135. Cindy Ng LW, Mackney J, Jenkins S, Hill K. Does exercise training change physical activity in people with COPD? A systematic review and metaanalysis. Chron Respir Dis 2012;9(1):17-26.

136.Lewko A, Bidgood PL, Jewell A, Garrod R. Evaluation of multidimensional COPD-related subjective fatigue following a Pulmonary Rehabilitation programme. Respir Med 2014;108(1):95-102.

137. Kim HC, Mofarrahi M, Hussain SN. Skeletal muscle dysfunction in patients with chronic obstructive pulmonary disease. Int J Chron Obstruct Pulmon Dis 2008;3(4):637-58.

138. Davis MP, Walsh D. Mechanisms of fatigue. J Support Oncol 2010;8(4):16474. 
139. Lopez Varela MV, Montes de Oca M, Halbert RJ, Muino A, Perez-Padilla $\mathrm{R}$, Talamo C, et al. Sex-related differences in COPD in five Latin American cities: the PLATINO study. Eur Respir J 2010;36(5):1034-41.

140. Rondelli RR, Dal Corso S, Simoes A, Malaguti C. Methods for the assessment of peripheral muscle fatigue and its energy and metabolic determinants in COPD. J Bras Pneumol 2009;35(11):1125-35.

141. Torres SH, Montes de Oca M, Loeb E, Mata A, Hernandez N. Gender and skeletal muscle characteristics in subjects with chronic obstructive pulmonary disease. Respir Med 2011;105(1):88-94.

142. Donaldson AV, Maddocks M, Martolini D, Polkey MI, Man WD. Muscle function in COPD: a complex interplay. Int J Chron Obstruct Pulmon Dis 2012;7:523-35.

143. Gea J, Agusti A, Roca J. Pathophysiology of muscle dysfunction in COPD. J Appl Physiol 2013;114(9):1222-34.

144. Haave E, Hyland ME, Engvik H. Improvements in exercise capacity during a 4-weeks pulmonary rehabilitation program for COPD patients do not correspond with improvements in self-reported health status or quality of life. Int J Chron Obstruct Pulmon Dis 2007;2(3):355-9.

145. Garrod R, Marshall J, Barley E, Jones PW. Predictors of success and failure in pulmonary rehabilitation. Eur Respir J 2006;27(4):788-94.

146. Robles PG, Brooks D, Goldstein R, Salbach N, Mathur S. Gender-

Associated Differences in Pulmonary Rehabilitation Outcomes in People With Chronic Obstructive Pulmonary Disease: A SYSTEMATIC REVIEW. J Cardiopulm Rehabil Prev 2013;Nov25[Epub ahead of print].

147. Pitta F, Troosters T, Probst VS, Spruit MA, Decramer M, Gosselink R.

Quantifying physical activity in daily life with questionnaires and motion sensors in COPD. Eur Respir J 2006;27(5):1040-55.

148. van Poppel MN, Chinapaw MJ, Mokkink LB, van Mechelen W, Terwee CB. Physical activity questionnaires for adults: a systematic review of measurement properties. Sports Med 2010;40(7):565-600.

149. Tomioka K, Iwamoto J, Saeki K, Okamoto N. Reliability and validity of the International Physical Activity Questionnaire (IPAQ) in elderly adults: the Fujiwara-kyo Study. J Epidemiol 2011;21(6):459-65.

150. Lenz ER, Suppe F, Gift AG, Pugh LC, Milligan RA. Collaborative development of middle-range nursing theories: toward a theory of unpleasant symptoms. ANS Adv Nurs Sci 1995;17(3):1-13.

151. Stridsman C, Lindberg A, Skar L. Fatigue in chronic obstructive pulmonary disease: a qualitative study of people's experiences. Scand J Caring Sci 2014;28(1):130-8. 
152. Burtin C, Saey D, Saglam M, Langer D, Gosselink R, Janssens W, et al. Effectiveness of exercise training in patients with COPD: the role of muscle fatigue. Eur Respir J 2012;40(2):338-44.

153. Mador MJ, Mogri M, Patel A. Contractile fatigue of the quadriceps muscle predicts improvement in exercise performance after pulmonary rehabilitation. J Cardiopulm Rehabil Prev 2014;34(1):54-61.

154. Sivori M, Bustamante L, Martinez Fraga A, Almeida M, Saenz C. Training response in COPD. Differences between fatigue-limited and dyspnealimited patients. Medicina (B Aires) 2011;71(2):120-6. 


\section{Papers}

The articles associated with this thesis have been removed for copyright reasons. For more details about these see:

http://urn.kb.se/resolve?urn=urn:nbn:se:liu:diva-105195 